\title{
Investigation of Candidate Genes and Mechanisms Underlying Obesity Associated Type 2 Diabetes Mellitus Using Bioinformatics Analysis and Screening of Small Drug Molecules
}

\section{Prashanth G}

Department of General Medicine, Basaveshwara Medical College, Chitradurga 577501, Karnataka, India.

\section{Basavaraj Vastrad}

Department of Biochemistry, Basaveshwar College of Pharmacy, Gadag, Karnataka 582103, India.

\section{Anandkumar Tengli}

Department of Pharmaceutical Chemistry, JSS College of Pharmacy, Mysuru and JSS Academy of Higher Education \& Research, Mysuru, Karnataka, 570015, India

Chanabasayya Vastrad ( $\sim$ channu.vastrad@gmail.com)

Biostatistics and Bioinformatics, Chanabasava Nilaya, Bharthinagar, Dharwad 580001, Karnataka, India.

\section{Iranna Kotturshetti}

Department of Ayurveda, Rajiv Gandhi Education Society`s Ayurvedic Medical College, Ron 562209, Karnataka, India.

\section{Research Article}

Keywords: obesity associated type 2 diabetes mellitus, differentially expressed gene, pathway, proteinprotein interaction network, miRNA-target genes regulatory network

Posted Date: December 11th, 2020

DOl: https://doi.org/10.21203/rs.3.rs-121659/v1

License: (9) This work is licensed under a Creative Commons Attribution 4.0 International License. Read Full License

Version of Record: A version of this preprint was published at BMC Endocrine Disorders on April 26th, 2021. See the published version at https://doi.org/10.1186/s12902-021-00718-5. 


\section{Abstract}

\section{Background}

Obesity associated type 2 diabetes mellitus is a metabolic disorder; however, the etiology of obesity associated type 2 diabetes mellitus remains largely unknown. There is an urgent need to further broaden the understanding of the development mechanism of obesity associated type 2 diabetes mellitus.

\section{Methods}

To screen the differentially expressed genes (DEGs) that may play essential roles in obesity associated type 2 diabetes mellitus, the public expression profiling by high throughput sequencing data (GSE143319) were downloaded and screened for DEGs. Then, Gene Ontology (GO) function analysis and REACTOME pathway analysis were performed. To screen hub and target genes, the protein-protein interaction network, miRNA-target genes regulatory network and TF-target gene regulatory network were constructed. The Receiver operating characteristic (ROC) curve analysis and RT- PCR analysis of hub genes in obesity associated type 2 diabetes mellitus were also analyzed. Final molecular docking studies performed for screening small drug molecules.

\section{Results}

There were 409 up regulated and 411 down regulated genes detected, and the biological processes of the $\mathrm{GO}$ analysis were enriched in regulation of ion transmembrane transport, intrinsic component of plasma membrane, transferase activity, transferring phosphorus-containing groups, cell adhesion, integral component of plasma membrane and signaling receptor binding, whereas, the REACTOME pathway analysis was enriched in integration of energy metabolism and extracellular matrix organization. The hub genes CEBPD, TP73, ESR2, TAB1, MAP3K5, FN1, UBD, RUNX1, PIK3R2 and TNF, which might play a essential role in obesity associated type 2 diabetes mellitus was further screened.

\section{Conclusions}

The present study could deepen the understanding of the molecular mechanism of obesity associated type 2 diabetes mellitus, which could be useful in developing clinical treatments of obesity associated type 2 diabetes mellitus.

\section{Introduction}

Obesity associated type 2 diabetes mellitus are a core challenge for metabolic disorder research around the globe [1]. Type 2 diabetes mellitus is characterized by insulin deficiency due to pancreatic $\beta$-cell inactivation and insulin resistance [2]. Genetic factors, hyperinsulinemia, atherogenic dyslipidemia, glucose intolerance, hypertension, prothrombic state, hyperuricemia, and polycystic ovary syndrome are the risk factors linked with progression of type 2 diabetes mellitus [3]. Obesity associated type 2 diabetes mellitus constitutes another main type of common and chronic disease that affects the vital organs such 
as heart [4], brain [5], kidney [6] and eye [7]. Do not fully resolve the etiology and advancement of obesity associated type 2 diabetes mellitus. Therefore, the potential molecular mechanisms add to the pathogenesis of type 2 diabetes mellitus remain to be precisely exhibit to find potential target genes for the avoidance and treatment of obesity associated type 2 diabetes mellitus.

Developing evidence has shown that genetic predisposition plays a key role in the advancement of obesity associated type 2 diabetes mellitus [8]. Recently, several genes and pathways have been found to participate in the occurrence and advancement of obesity associated type 2 diabetes mellitus [9], including FGF21 [10], pro-opiomelanocortin (POMC) [11], PI3K/AKT pathway [12] and JAK/STAT pathway [13]. However, the current knowledge is insufficient to explain how these crucial genes are associated with advancement of obesity associated type 2 diabetes mellitus. Therefore, there is a great need to find new biomarkers and to advance novel techniques to enlighten the mechanism controlling obesity associated type 2 diabetes mellitus.

Bioinformatics analysis of expression profiling by high throughput sequencing has shown great promise to discover potential key genes and signaling pathways with roles in metabolic disorder [14], to identify new biomarkers and biological processes implicated in obesity associated type 2 diabetes mellitus. In this investigation, using bioinformatics analysis, we aimed to investigate expression profiling by high throughput sequencing data from dataset to determine differentially expressed genes (DEGs) and significant pathways in obesity associated type 2 diabetes mellitus. After searching the Gene Expression Omnibus (GEO) database [15], we identified dataset GSE143319 with RNA sequencing data of T2DM. Subsequently, we performed Gene Ontology (GO) enrichment analysis of the signaling pathways involved, and a protein-protein interaction (PPI) network, miRNA-target genes regulatory network, TFtarget gene regulatory network constructed and analyzed, and validation of hub genes were developed, all of which will improve our understanding of the pathogenesis of obesity associated type 2 diabetes mellitus. Final molecular docking studies performed for screening small drug molecules.

\section{Materials And Methods}

\section{RNA sequencing data}

The expression profiling by high throughput sequencing data for GSE143319 deposited by Ding et al [16] into the GEO database were obtained on the GPL20301 platform (Illumina HiSeq 4000 (Homo sapiens)). The expression profiling by high throughput sequencing is provided for 30 samples, including 15 samples of a metabolically healthy obese and 15 samples of a metabolically unhealthy obese.

\section{Identification of DEGs}

The limma [17] in R bioconductor package was utilized to screen differentially expressed genes (DEGs) between metabolically healthy obese and metabolically unhealthy obese. These DEGs were identified as important genes that may play an important role in the development of T2DM with obesity. The cutoff 
criterion were $\mid \log$ fold change $(\mathrm{FC}) \mid>0.2587$ for up regulated genes, were $\mid \log$ fold change $(\mathrm{FC}) \mid<-0.2825$ for down regulated genes and $\mathrm{P}<0.05$.

\section{Gene ontology and pathway enrichment analyses}

ToppGene (ToppFun) (https://toppgene.cchmc.org/enrichment.jsp) [18] which is a useful online platform database that integrates biologic data and provides a comprehensive set of functional annotation information of genes as well as proteins for users to analyze the functions or signaling pathways. GO (http://geneontology.org/) [19] enrichment analysis (biologic processes [BPs], cellular components [CCs], and molecular functions [MFs]) is a strong bioinformatics tool to analyze and annotate genes. The REACTOME (https://reactome.org/) [20] is a pathway database resource for understanding high-level gene functions and linking genomic information from large-scale molecular data sets. To analyze the function of the diagnosed DEGs, biologic analyses were performed using GO enrichment and REACTOME pathway analysis via ToppGene online database.

\section{PPI network construction and module analysis}

IMEX interactome (https://www.imexconsortium.org/) [21] online database was using to predicted the PPI network information. Analyzing the interactions and functions between DEGs may provide information about the mechanisms of generation and development of disease (PPI score>0.4). Cytoscape (version 3.8.2) (www.cytoscape.org) is a bioinformatics platform for constructing and visualizing molecular interaction networks [22]. Therefore, the node degree [23], betweenness centrality [24], stress centrality [25], closeness centrality [26] were statistically analyzed in networks using Network Analyzer to obtain the significant nodes or hub genes in the PPI network. Network Analyzer, a Java plugin for Cytoscape, is capable of predicting key nodes in a given network by several topological algorithms. The plug-in Molecular Complex Detection (MCODE) of Cytoscape was applied to detect densely connected regions in PPI networks. The PPI networks were constructed using Cytoscape and the most significant module in the PPI networks was selected using PEWCC1 (http://apps.cytoscape.org/apps/PEWCC1) [27]. The criteria for selection were set as follows: Max depth $=100$, degree cut-off $=2$, Node score cut-off $=0.2$, PEWCC1 scores $>5$, and K-score $=2$.

\section{Target gene - miRNA genes regulatory network construction and analysis}

T2DM with obesity relating miRNAs and experimentally validated target genes were extracted from miRNet database (https://www.mirnet.ca/) [28]. T2DM with obesity relating miRNA-target gene pairs were identified through comparing the DEGs with the downloaded miRNA-target pairs. Then the target genes miRNA regulatory network was constructed using Cytoscape software.

\section{Target gene - TF network regulatory construction and analysis}

T2DM with obesity relating TFs and experimentally validated target genes were extracted from TFs database NetworkAnalyst database (https://www.networkanalyst.ca/) [29]. T2DM with obesity relating 
TF-target gene pairs were identified through comparing the DEGs with the downloaded TF-target pairs. Then the target genes -TF regulatory network was constructed using Cytoscape software.

\section{Receiver operating characteristic (ROC) curve analysis}

The ROC curve was used to calculate classifiers in bioinformatics applications. To further assess the predictive accuracy of the DEGs, ROC analysis was performed to discriminate metabolically healthy obese from metabolically unhealthy obese. ROC curves for hub genes were generated using $\mathrm{PROC}$ in $\mathrm{R}$ [30] based on the obtained DEGs and their expression profiling by high throughput sequencing data from dataset. The area under the ROC curve (AUC) was evaluated and used to compare the diagnostic value of hub genes.

\section{Validation of the expression levels of candidate genes by RT-PCR}

Quantitative RT-PCR was conducted to validate the expressions of these hub genes in obesity with T2DM. Total RNAs were extracted from Primary Subcutaneous Pre-adipocytes; Normal, Human (ATCC® PCS-210-010 ${ }^{\text {TM }}$ ) and 3T3-L1 cells (ATCC $®$ CL-173) using TRI Reagent ${ }^{\circledR}$ (Sigma, USA) according to instruction, followed by reverse transcription with Reverse transcription cDNA kit (Thermo Fisher Scientific, Waltham, MA, USA) and cDNA amplification through 7 Flex real-time PCR system (Thermo Fisher Scientific, Waltham, MA, USA). The expressions of these hub genes were normalized to against beta-actin expression. The data were calculated by the $2^{-\Delta \Delta C t}$ method [31] . Primers used in the current investigation were listed in Table 1.

\section{Molecular docking studies}

The Surflex-Docking docking studies for the designed molecules were performed using module SYBYL-X 2.0 perpetual software. Using ChemDraw Tools, the molecules were sketched and imported and saved into sdf. Format using open free software from Babel. The co-crystallised protein structures of CEBPD, TP73, ESR2, TAB1 and MAP3K5 of its PDB code 3L4W, 2XWC, 1U3Q, 5NZZ \& 2CLQwas extracted from Protein Data Bank 1262 [32-36]. Together with the TRIPOS force field, GasteigerHuckel (GH) charges were added to all designed derivatives for the structure optimization process. Furthermore, energy minimization was carried out using MMFF94s and MMFF94 algorithm process. The processing of protein was accomplished after the incorporation of protein. The co-crystallized ligand and all water molecules were expelled from the crystal structure; more hydrogen was added and the side chain was optimized. TRIPOS force field was used to minimize complexity of structure. The interaction efficiency of the compounds with the receptor was expressed in $\mathrm{kcal} / \mathrm{mol}$ units by the Surflex-Dock score. The best spot between the protein and the ligand was inserted into the molecular region. The visualisation of ligand interaction with receptor is done by using discovery studio visualizer.

\section{Results}


As presented in the cluster heat map of Fig. 1, total 820 DEGs, comprising 409 up regulated and 411 down regulated genes, were identified between metabolically healthy obese samples and metabolically unhealthy obese samples. DEGs expressions were illustrated by volcano plot (Fig.2), and the top up regulated and down regulated DEGs are listed in Table 2.

\section{Gene ontology and pathway enrichment analyses}

DEGs were divided into up regulated genes and down regulated genes. GO categories and REACTOME pathway enrichment analysis were conducted for these genes. Results of GO categories were presented by functional groups, which were group BP, CC, and MF and are listed in Table 3. In group BP, up regulated genes were significantly enriched in regulation of ion transmembrane transport and oxoacid metabolic process, while the down regulated genes were mainly enriched in cell adhesion and response to endogenous stimulus. For group CC, up regulated genes mainly enriched in intrinsic component of plasma membrane and mitochondrion, and down regulated genes mainly enriched in integral component of plasma membrane and supra molecular fiber. In addition, GO results of group MF showed that up regulated genes mainly enriched in transferase activity, transferring phosphorus-containing groups and transporter activity and down regulated genes mainly enriched in signaling receptor binding and molecular transducer activity. Several significant enriched pathways were acquired through REACTOME pathway analysis (Table 4). The enriched pathways for up regulated genes included integration of energy metabolism and neuronal system. Meanwhile, down regulated genes strikingly enriched in extracellular matrix organization and GPCR ligand binding.

\section{PPI network construction and module analysis}

PPI network complex consisted of 3648 nodes and 6305 edges, wherein node and edge represented gene and interaction between 2 genes (Fig. 3A). Moreover, CEBPD, TP73, ESR2, TAB1, MAP3K5, FN1, UBD, RUNX1, PIK3R2 and TNF were identified as central genes and are listed in Table 5. In addition, module analysis was conducted to detect the highly connected regions of PPI network, and two significant modules were obtained (Fig.3B and Fig.3C). Further GO and pathway enrichment analysis revealed that genes in these modules were mostly implicated in regulation of ion transmembrane transport, oxoacid metabolic process, intrinsic component of plasma membrane, extracellular matrix organization and supra molecular fiber.

\section{Target gene - miRNA regulatory network construction and analysis}

The target genes - miRNA regulatory network was constructed, including 1982 miRNAs and 245 target genes. As shown in the integrated target genes - miRNA regulatory network (Fig. 4), FASN targeted 147 miRNAs (ex, hsa-mir-4314), SREBF1 targeted 81 miRNAs (ex, hsa-mir-5688), CKB targeted 72 miRNAs (ex, hsa-mir-583), CACNA1A targeted 69 miRNAs (ex, hsa-mir-632), ESR2 targeted 61 miRNAs (ex, hsa-mir3176), MAP1B targeted 249 miRNAs (ex, hsa-mir-1299), RUNX1 targeted 125 miRNAs (ex, hsa-mir-4530), PRNP targeted 106 miRNAs (ex, hsa-mir-4477a), FN1 targeted 105 miRNAs (ex, hsa-mir-606) and DAB2 targeted 75 miRNAs (ex, hsa-mir-1343-3p6) and are listed in Table 6. 


\section{Target gene-TF s regulatory network construction and analysis}

The target genes -TF regulatory network was constructed, including 333 TFs and 204 target genes. As shown in the integrated target genes -TF regulatory network (Fig. 5), SREBF1 targeted 94 TFs (ex, ATF4), FASN targeted 71 TFs (ex, CUX1), SLC9A3R1 targeted 63 TFs (ex, MBD2), CKB targeted 50 TFs (ex, IRF4), TGM2 targeted 50 TFs (ex, SIN3A), PIK3R2 targeted 73 TFs (ex, ZNF143), FLNC targeted 53 TFs (ex, SMARCE1), RUNX1 targeted 53 TFs (ex, ZBTB7A), FN1 targeted 45 TFs (ex, CREB1) and TRIM63 targeted 22 TFs (ex, RELA) and are listed in Table 6.

\section{Receiver operating characteristic (ROC) curve analysis}

The ROC curve was used to assess the predictive accuracy of hub genes. AUC was determined and used to prefer the most appropriate cut-off gene expression levels. ROC curves and AUC values are presented in Fig. 6. All AUC values exceeded 0.72, while the up regulated genes CEBPD, TP73, ESR2, TAB1 and MAP3K5, and down regulated genes FN1, UBD, RUNX1, PIK3R2 and TNF had AUC values $>0.75$.

\section{Validation of the expression levels of candidate genes by RT-PCR}

To further verify the expression level of hub genes in obese samples, RT-qPCR was performed to calculate the mRNA levels of the ten hub genes identified in the present study (CEBPD, TP73, ESR2, TAB1, MAP3K5, FN1, UBD, RUNX1, PIK3R2 and TNF) in obese samples. As illustrated in Fig. 7, the expression of CEBPD, TP73, ESR2, TAB1, MAP3K5 were significantly up regulated in obese samples compared with normal control tissues, while FN1, UBD, RUNX1, PIK3R2 and TNF were significantly down regulated in obese samples compared with normal control tissues. The present RT-PCR results were in line with the prior bioinformatics analysis, suggesting that these essential genes might be associated to the molecular mechanism underlying obesity associated type 2 diabetes mellitus.

\section{Molecular docking studies}

In the current research, the docking simulation was conducted to recognize the active site conformation and major interactions responsible for complex stability with the binding sites receptor. Drug design software Sybyl X 2.1 was used to perform docking experiments on novel molecules containing thiazolidindioneheterocyclic ring. Molecules containing the heterocyclic ring of thiazolidinedione are constructed based on the pioglitazone structure and are most widely used alone or in conjunction with other anti-diabetic drugs. Obesity associated type 2 diabetes mellitus is a chronic disorder that prevents insulin from being used by the body the way it should. It's said that people with obesity associated type 2 diabetes mellitus have insulin resistance, oral hypoglycaemic agents are used either alone or in combination of two or more drugs. Pioglitazone (Glitazones) are commonly used either alone or in combination in obesity associated type 2 diabetes mellitus. The one protein in each over expressed genes in obesity associated type 2 diabetes mellitus are selected for docking studies. The X-RAY crystallographic structure of one protein from each over-expressed genes of CEBPD (CCAAT enhancer binding protein delta), TP73 (tumour protein P73), ESR2 (Estrogen receptor 2), TAB1 (TGF-beta activated 
kinase 1 MAP3K7 binding protein 1) and MAP3K5 (Mitogen activated protein kinase kinasekinase 5) and their co-crystallized PDB code of 4LY9, 2XWC, 2IOG, 5NZZ and 5UP3 respectively were selected for docking. The examination of the designed molecules were performed to recognize the potential molecule. The foremost of the designed molecules obtained C-score greater than 6 and are said to be active. A total of 24 designed molecules few molecules have excellent good binding energy (C-score) greater than 8 respectively . Few of the designed molecules obtained good binding scores such as molecule TZP20, TZPS8, TZP22, TZPS10 (Fig.8) obtained binding core of 12.212, 11.489, 11.013 and 10.851 with 5UP3 and molecule TZP22, TZPS8, TZPS10 obtained binding score of 9.482, 9.329 and 9.252 with 2XWC and molecule TZP20, TZPS10 obtained binding score 7.359 and 6.848 with 5NZZ and molecule TZP22, TZP21, TZPS9 obtained binding score $11.053,10.716$ and 10.669 with 2IOG respectively. The molecule TZP23, TZPS5, TZPS2 obtained bind score 4.336 to 4.319 with $5 \mathrm{NZZ}$ and molecule TZPS10 of binding core 4.633 with 2 IOG respectively. The binding score of the predicted molecules are compared with that of the standard Pioglitaone obtained bind score of 10.1314, 9.834, 9.8244, 9.8284 and 7.4321 with 2IOG, 2XWC, 4LY9, 5UP3 and 5NZZ, the values are depicted in Table 7. The molecule TZP22 obtained good binding score with all proteins and hydrogen bonding and other bonding interactions with amino acids with protein code 2IOG are depicted by 3D (Fig Fig.9) and 2D figures (Fig.10).

\section{Discussion}

Obesity associated type 2 diabetes mellitus is the most common aggressive metabolic disorder [37]. However, the most key challenge in treating obesity associated type 2 diabetes mellitus is the presence of complexity [38]. Although previous investigations have reported various potential molecular markers linked with the advancement of obesity associated type 2 diabetes mellitus, the potential molecular mechanism underlying its pathogenesis has not been generally studied [39]. In the present investigation, a total of 820 DEGs were identified, containing 409 up regulated genes and 411 down regulated genes. SULT1C2 [40] and UBD (ubiquitin D) [41] were responsible for progression of kidney diseases, but these genes might be liable for advancement of obesity associated T2DM. HLA-DQA1 was associated with progression of T2DM [42]. SPX (spexin hormone) [43] and APOB (apolipoprotein B) [44] are a critical proteins plays an important role in obesity associated type 2 diabetes mellitus.

The GO and pathway enrichment analysis of DEG are closely related to obesity associated type 2 diabetes mellitus genes and advancement. KCNE5 [45], SHANK3 [46], CASQ2 [47], EDNRA (endothelin receptor type A) [48], EPHB4 [49], ALPK3 [50], WNT11 [51], IRAK2 [52], FBN1 [53], SFRP2 [54], CLCA2 [55], NEXN (nexilin F-actin binding protein) [56], PALLD (palladin, cytoskeletal associated protein) [57], DAB2 [58], NRP2 [59], THBS2 [60], CSF1R [61], KCNA2 [62], CACNA1C [63], F2R [64], UCHL1 [65], CCL18 [66], ITGB1BP2 [67] and FMOD (fibromodulin) [68] were reportedly involved in cardio vascular diseases, but these genes might be key for progression of obesity associated type 2 diabetes mellitus. Hu et al. [69], Liu et al. [70], Eltokhi et al. [71], Cai et al. [72], Pfeiffer et al. [73], Lin et al. [74], Royer-Zemmour et al. [75], Pastor et al. [76], Goodspeed et al. [77], Zhang et al. [78], Rogers et al. [79], Su et al. [80] and Foale et al. [81] reported that NRXN1, CRHR1, SHANK2, PSEN2, CKB (creatine kinase B), CD200R1, SRPX2, PTPRZ1, SLC6A1, GABRB2, KCNA1, ASAH1 and LING01 were linked with progression of neuropsychiatric 
disorders, but these genes might be involved in advancement of obesity associated type 2 diabetes mellitus. Reports indicate that SPHK2 [82], NPC1L1 [83], CNTFR (ciliaryneurotrophic factor receptor) [84], SLC2A4 [85], EDA (ectodysplasin A) [86], TGM2 [87], GCK (glucokinase) [88], FASN (fatty acid synthase) [89], FAP (fibroblast activation protein alpha) [90], PRNP (prion protein) [91], LYVE1 [92], SERPINE1 [93], TNF (tumor necrosis factor) [94], FASLG (Fas ligand) [95], HGF (hepatocyte growth factor) [96], FNDC5 [97], LBP (lipopolysaccharide binding protein) [98] and LOX (lysyl oxidase) [99] were found in obesity associated T2DM. Hirai et al [100], Vuori et al [101], Porta et al [102], Nomoto et al [103] and Blindbæk et al [104] demonstrates that VAMP2, CACNB2, SLC19A3, PFKFB3 and MFAP4 are essential for progression of type 1 diabetes, but these genes might be key for advancement of obesity associated type 2 diabetes mellitus. CACNA1A [105], ALK (ALK receptor tyrosine kinase) [106], SLC4A4 [107], STOX1 [108], COL3A1 [109], VNN1 [110], SLC4A7 [111], BDKRB2 [112], DRD1 [113] and LPAR1 [114] have reported significantly linked with hypertension, but these genes might be crucial for progression of obesity associated type 2 diabetes mellitus. KCNE2 [115], DLL1 [116], ACVR1C [117], RGS3 [118], MLXIPL (MLX interacting protein like) [119], PAG1 [120], SLC2A10 [121] and GRB14 [122] play important role in type 2 diabetes mellitus progression. A recent investigation has indicated that GPIHBP1 [123], FGFRL1 [124], DAPK2 [125], MAP3K5 [126], ANKK1 [127], GK (glycerol kinase) [128], SPHK1 [129], GNG3 [130], FSTL3 [131], SLIT2 [132], CCDC80 [133], RND3 [134], PTGER4 [135], RUNX1 [136], ADAM12 [137], OLR1 [138], THBS1 [139], CD28 [140], TRPV4 [141], ATRN (attractin) [142], MRC1 [143], SEMA3C [144], HTR2B [145], NOX4 [146], TACR1 [147], BAMBI [148], PDGFD (platelet derived growth factor D) [149], APLN (apelin) [150], MFAP5 [151] and LUM (lumican) [152] are associated with a development of obesity. A previous investigation found that DDR1 [153], TAB1 [154], NEK8 [155], SERPINE2 [156], FCGR2B [157], ANGPT2 [158], FN1 [159], SOCS5 [158], SMOC2 [160], CD2 [161] and SCN9A [162] expression were associated with a kidney diseases, but these genes might be responsible for advancement of obesity associated type 2 diabetes mellitus.

In addition, an investigation reported that hub genes serve an essential role in maintaining the entire PPI network and its modules are indispensable. Investigation has demonstrated that CEBPD (CCAAT enhancer binding protein delta) is one of the most important genes involved in obesity [163]. An investigation by Domingues-Montanari et al. [164] demonstrated that ESR2 is key for progression of cardio vascular disease, but this gene might be responsible for progression of obesity associated type 2 diabetes mellitus. TP73, PIK3R2, SLC9A3R1, KRT5, KRT14 and TFAP2C are novel biomarkers for pathogenesis of obesity associated type 2 diabetes mellitus.

The miRNA-target gene regulatory network and TF-target gene regulatory network highlighted in the current investigation provides new theoretical guidance for further exploring the mechanism of obesity associated type 2 diabetes mellitus and provides a new perspective for understanding the underlying biological processes of obesity associated type 2 diabetes mellitus, and miRNA and TF targeted therapy. Eberlé et al [165], Cheng et al [166], Cavallari et al [167], Qi et al [168] and Yan et al [169] indicated that SREBF1, MBD2, IRF4, CREB1 and RELA (Nuclear factor-kB) were responsible for advancement of obesity associated type 2 diabetes mellitus. Matsha et al [170] and Ding et al [171] demonstrated that hsa-mir1299 and hsa-mir-4530 were liable for progression of type 2 diabetes mellitus. Hall et al [172] and 
Salazar-Mendiguchía et al [173] reported that FLNC (filamin C) and TRIM63were involved in progression of cardio vascular disease, but these genes might be essential for development of obesity associated type 2 diabetes mellitus. Xiao et al [174], Stratigopoulos et al [175] and Zhou et al [176] noted that ATF4, CUX1 and ZBTB7A were responsible for advancement of obesity. MAP1B, hsa-mir-4314, hsa-mir-5688, hsa-mir-583, hsa-mir-632, hsa-mir-3176, hsa-mir-4477a, hsa-mir-606, hsa-mir-1343-3p6, SIN3A, ZNF143 and SMARCE1 are the novel biomarkers for pathogenesis of obesity associated type 2 diabetes mellitus.

In conclusion, with the integrated bioinformatics analysis for expression profiling by high throughput sequencing in obesity associated type 2 diabetes mellitus, Ten hub genes associated with the pathogenesis and prognosis of obesity associated type 2 diabetes, including CEBPD, TP73, ESR2, TAB1, MAP3K5, FN1, UBD, RUNX1, PIK3R2 and TNF. These hub genes were all unregulated in obesity associated type 2 diabetes mellitus and first five (CEBPD, TP73, ESR2, TAB1 and MAP3K5) of them might be linked with targeted therapy. These hub genes may be regarded as new diagnostic and prognostic biomarkers for obesity associated type 2 diabetes mellitus. However, further in-depth investigation (in vivo and in vitro experiment) is necessary to elucidate the biological function of these genes in obesity associated type 2 diabetes mellitus.

\section{Declarations}

\section{Acknowledgement}

I thank Jun Yoshino, Washington University School of Medicine, Medicine, St. Louis, USA, very much, the author who deposited their profiling by high throughput sequencing dataset, GSE143319, into the public GEO database.

\section{Conflict of interest}

The authors declare that they have no conflict of interest.

\section{Ethical approval}

This article does not contain any studies with human participants or animals performed by any of the authors.

\section{Informed consent}

No informed consent because this study does not contain human or animals participants.

\section{Availability of data and materials}

The datasets supporting the conclusions of this article are available in the GEO (Gene Expression Omnibus) (https://www.ncbi.nlm.nih.gov/geo/) repository. [(GSE143319) (https://www.ncbi.nlm.nih.gov/geo/query/acc.cgi?acc=GSE143319] 


\section{Consent for publication}

Not applicable.

\section{Competing interests}

The authors declare that they have no competing interests.

\section{Author Contributions}

P. G - Methodology and validation

B. $V$ - Writing original draft, and review and editing

A. T - Formal analysis and validation

C. V - Software and investigation

I. K - Supervision and resources

\section{Authors}

Prashanth G

Basavaraj Vastrad

Anandkumar Tengli

Chanabasayya Vastrad

Iranna Kotturshetti
ORCID ID: 0000-0003-2571-5734

ORCID ID: 0000-0003-2202-7637

ORCID ID: 0000-0001-8076-928X

ORCID ID: 0000-0003-3615-4450

ORCID ID: 0000-0003-1988-7345

\section{References}

1. Pulgaron ER, Delamater AM. Obesity and type 2 diabetes in children: epidemiology and treatment. Curr Diab Rep. 2014;14(8):508. doi:1007/s11892-014-0508-y

2. Taylor R. Type 2 diabetes: etiology and reversibility. Diabetes Care. 2013;36(4):1047-1055. doi:2337/dc12-1805

3. Catalán V, Gómez-Ambrosi J, Rodríguez A, Ramírez B, Rotellar F, Valentí V, Silva C, Gil MJ, Salvador J, Frühbeck G. Increased circulating and visceral adipose tissue expression levels of YKL-40 in obesityassociated type 2 diabetes are related to inflammation: impact of conventional weight loss and gastric bypass. J Clin Endocrinol Metab. 2011;96(1):200-209. doi:1210/jc.2010-0994

4. Fukushima A, Lopaschuk GD. Acetylation control of cardiac fatty acid $\beta$-oxidation and energy metabolism in obesity, diabetes, and heart failure. Biochim Biophys Acta. 2016;1862(12):2211-2220. doi:1016/j.bbadis.2016.07.020 
5. Pugazhenthi S, Qin L, Reddy PH. Common neurodegenerative pathways in obesity, diabetes, and Alzheimer's disease. Biochim Biophys Acta Mol Basis Dis. 2017;1863(5):1037-1045. doi:1016/j.bbadis.2016.04.017

6. Chagnac A, Zingerman B, Rozen-Zvi B, Herman-Edelstein M. Consequences of Glomerular Hyperfiltration: The Role of Physical Forces in the Pathogenesis of Chronic Kidney Disease in Diabetes and Obesity. Nephron. 2019;143(1):38-42. doi:1159/000499486

7. Cheung N, Wong TY. Obesity and eye diseases. Surv Ophthalmol. 2007;52(2):180-195. doi:1016/j.survophthal.2006.12.003

8. Temelkova-Kurktschiev T, Stefanov T. Lifestyle and genetics in obesity and type 2 diabetes. Exp Clin Endocrinol Diabetes. 2012;120(1):1-6. doi:1055/s-0031-1285832

9. Wen X, Qian C, Zhang Y, Wu R, Lu L, Zhu C, Cheng X, Cui R, You H, Mei F, et al. Key pathway and gene alterations in the gastric mucosa associated with obesity and obesity-related diabetes. J Cell Biochem. 2019;120(4):6763-6771. doi:1002/jcb.27976

10. Kruse R, Vienberg SG, Vind BF, Andersen B, Højlund K. Effects of insulin and exercise training on FGF21, its receptors and target genes in obesity and type 2 diabetes. Diabetologia. 2017;60(10):2042-2051. doi:1007/s00125-017-4373-5

11. Davison LJ, Holder A, Catchpole B, O'Callaghan CA. The Canine POMC Gene, Obesity in Labrador Retrievers and Susceptibility to Diabetes Mellitus. J Vet Intern Med. 2017;31(2):343-348. doi:1111/jvim. 14636

12. Huang X, Liu G, Guo J, Su Z. The PI3K/AKT pathway in obesity and type 2 diabetes. Int J Biol Sci. 2018;14(11):1483-1496. doi:7150/ijbs.27173

13. Gurzov EN, Stanley WJ, Pappas EG, Thomas HE, Gough DJ. The JAK/STAT pathway in obesity and diabetes. FEBS J. 2016;283(16):3002-3015. doi:1111/febs.13709

14. Xin Y, Kim J, Okamoto H, Ni M, Wei Y, Adler C, Murphy AJ, Yancopoulos GD, Lin C, Gromada J. RNA Sequencing of Single Human Islet Cells Reveals Type 2 Diabetes Genes. Cell Metab. 2016;24(4):608615. doi:1016/j.cmet.2016.08.018

15. Clough E, Barrett T. The Gene Expression Omnibus Database. Methods Mol Biol. 2016;1418:93-110. doi:1007/978-1-4939-3578-9_5

16. Ding X, lyer R, Novotny C, Metzger D, Zhou HH, Smith GI, Yoshino M, Yoshino J, Klein S, Swaminath G, et al. Inhibition of Grb14, a negative modulator of insulin signaling, improves glucose homeostasis without causing cardiac dysfunction. Sci Rep. 2020;10(1):3417. doi:1038/s41598-020-60290-1

17. Ritchie ME, Phipson B, Wu D, Hu Y, Law CW, Shi W, Smyth GK. limma powers differential expression analyses for RNA-sequencing and microarray studies. Nucleic Acids Res. 2015;43(7):e47. doi:1093/nar/gkv007

18. Chen J, Bardes EE, Aronow BJ, Jegga AG. ToppGene Suite for gene list enrichment analysis and candidate gene prioritization. Nucleic Acids Res. 2009;37(Web Server issue):W305-W311. doi:1093/nar/gkp427 
19. Thomas PD. The Gene Ontology and the Meaning of Biological Function. Methods Mol Biol. 2017;1446:15-24. doi:1007/978-1-4939-3743-1_2

20. Fabregat A, Jupe S, Matthews L, Sidiropoulos K, Gillespie M, Garapati P, Haw R, Jassal B, Korninger F, May B et al The Reactome Pathway Knowledgebase. Nucleic Acids Res. 2018;46(D1):D649-D655. doi:1093/nar/gkx1132

21. Orchard S, Kerrien S, Abbani S, Aranda B, Bhate J, Bidwell S, Bridge A, Briganti L, Brinkman FS, Cesareni $\mathrm{G}$, et al. Protein interaction data curation: the International Molecular Exchange (IMEx) consortium . Nat Methods. 2012;9(4):345-350. doi:1038/nmeth.1931

22. Shannon P, Markiel A, Ozier O, Baliga NS, Wang JT, Ramage D, Amin N, Schwikowski B, Ideker T Cytoscape: a software environment for integrated models of biomolecular interaction networks. Genome Res 2003;13(11):2498-2504. doi:1101/gr.1239303

23. Przulj N, Wigle DA, Jurisica I. Functional topology in a network of protein interactions. Bioinformatics. 2004;20(3):340-348. doi:1093/bioinformatics/btg415

24. Nguyen TP, Liu WC, Jordán F. Inferring pleiotropy by network analysis: linked diseases in the human PPI network. BMC Syst Biol. 2011;5:179. Published 2011 Oct 31. doi:1186/1752-0509-5-179

25. Shi Z, Zhang B. Fast network centrality analysis using GPUs. BMC Bioinformatics. 2011;12:149. doi:1186/1471-2105-12-149

26. Fadhal E, Gamieldien J, Mwambene EC. Protein interaction networks as metric spaces: a novel perspective on distribution of hubs. BMC Syst Biol. 2014;8:6. doi:1186/1752-0509-8-6

27. Zaki N, Efımov D, Berengueres J. Protein complex detection using interaction reliability assessment and weighted clustering coefficient. BMC Bioinformatics. 2013;14:163. doi:1186/1471-2105-14

28. Fan Y, Xia J (2018) miRNet-Functional Analysis and Visual Exploration of miRNA-Target Interactions in a Network Context. Methods Mol Biol 1819:215-233. doi:1007/978-1-4939-8618-7_10

29. Zhou G, Soufan O, Ewald J, Hancock REW, Basu N, Xia J (2019) NetworkAnalyst 3.0: a visual analytics platform for comprehensive gene expression profiling and meta-analysis. Nucleic Acids Res 47:W234-W241. doi:1093/nar/gkz240

30. Robin X, Turck N, Hainard A, Tiberti N, Lisacek F, Sanchez JC, Müller M. pROC: an open-source package for $\mathrm{R}$ and $\mathrm{S}+$ to analyze and compare ROC curves. BMC Bioinformatics 2011;12:77. doi:1186/1471-2105-12-77

31. Livak KJ, Schmittgen TD. Analysis of relative gene expression data using real-time quantitative PCR and the 2(-Delta Delta C(T)) Method. Methods. 2001;25(4):402-408. doi:1006/meth.2001.

32. Naim MJ, Alam O, Alam MJ, Hassan MQ, Siddiqui N, Naidu VGM, Alam MI. Design, synthesis and molecular docking of thiazolidinedione based benzene sulphonamide derivatives containing pyrazole core as potential anti-diabetic agents. Bioorg Chem. 2018;76:98-112. doi:1016/j.bioorg.2017.11.010

33. Mohammadi-Khanaposhtani M, Rezaei S, Khalifeh R, Imanparast S, Faramarzi MA, Bahadorikhalili S, Safavi M, Bandarian F, Nasli Esfahani E, Mahdavi M, et al. Design, synthesis, docking study, a- 
glucosidase inhibition, and cytotoxic activities of acridine linked to thioacetamides as novel agents in treatment of type 2 diabetes. Bioorg Chem. 2018;80:288-295. doi:1016/j.bioorg.2018.06.035

34. Rojas LB, Gomes MB. Metformin: an old but still the best treatment for type 2 diabetes. Diabetol Metab Syndr. 2013;5(1):6. doi:1186/1758-5996-5-6

35. Thakral S, Narang R, Kumar M, Singh V. Synthesis, molecular docking and molecular dynamic simulation studies of 2-chloro-5-[(4-chlorophenyl) sulfamoyl]-N-(alkyl/aryl)-4-nitrobenzamide derivatives as antidiabetic agents. BMC chemistry. 2020;14(1):1-6. doi:10.1186/s13065-020-00703-4

36. Srikanth Kumar K, Lakshmana Rao A, Basaveswara Rao MV. Design, synthesis, biological evaluation and molecular docking studies of novel 3-substituted-5-[(indol-3-yl)methylene]-thiazolidine-2,4-dione derivatives. Heliyon. 2018;4(9):e00807. doi:10.1016/j.heliyon.2018.e00807

37. Mohammad S, Ahmad J. Management of obesity in patients with type 2 diabetes mellitus in primary care. Diabetes Metab Syndr. 2016;10(3):171-181. doi:1016/j.dsx.2016.01.017

38. Rao M, Gao C, Xu L, Jiang L, Zhu J, Chen G, Law BYK, Xu Y. Effect of Inulin-Type Carbohydrates on Insulin Resistance in Patients with Type 2 Diabetes and Obesity: A Systematic Review and MetaAnalysis. J Diabetes Res. 2019;2019:5101423. doi:1155/2019/5101423

39. Al-Sulaiti H, Diboun I, Agha MV, et al. Metabolic signature of obesity-associated insulin resistance and type 2 diabetes. J TransI Med. 2019;17(1):348. doi:1186/s12967-019-2096-8

40. Sugimura K, Tanaka T, Tanaka Y, Takano H, Kanagawa K, Sakamoto N, Ikemoto S, Kawashima H, Nakatani T. Decreased sulfotransferase SULT1C2 gene expression in DPT-induced polycystic kidney. Kidney Int. 2002;62(3):757-762. doi:1046/j.1523-1755.2002.00512.x

41. Zhang JY, Wang M, Tian L, Genovese G, Yan P, Wilson JG, Thadhani R, Mottl AK, Appel GB, Bick AG, et al. UBD modifies APOL1-induced kidney disease risk. Proc Natl Acad Sci U S A. 2018;115(13):3446-3451. doi:1073/pnas.1716113115

42. Ma ZJ, Sun P, Guo G, Zhang R, Chen LM. Association of the HLA-DQA1 and HLA-DQB1 Alleles in Type 2 Diabetes Mellitus and Diabetic Nephropathy in the Han Ethnicity of China. J Diabetes Res. 2013;2013:452537. doi:1155/2013/452537

43. Kołodziejski PA, Pruszyńska-Oszmałek E, Korek E, Sassek M, Szczepankiewicz D, Kaczmarek P, Nogowski L, Maćkowiak P, Nowak KW, Krauss H, et al. Serum levels of spexin and kisspeptin negatively correlate with obesity and insulin resistance in women. Physiol Res. 2018;67(1):45-56. doi:33549/physiolres.933467

44. Onat A, Can G, Hergenç G, Yazici M, Karabulut A, Albayrak S. Serum apolipoprotein B predicts dyslipidemia, metabolic syndrome and, in women, hypertension and diabetes, independent of markers of central obesity and inflammation. Int J Obes (Lond). 2007;31(7):1119-1125. doi:1038/sj.ijo.0803552

45. Ravn LS, Hofman-Bang J, Dixen U, Larsen SO, Jensen G, Hauns $\varnothing$ S, Svendsen JH, Christiansen M. Relation of 97T polymorphism in KCNE5 to risk of atrial fibrillation. Am J Cardiol. 2005;96(3):405407. doi:1016/j.amjcard.2005.03.086 
46. Man W, Gu J, Wang B, Zhang M, Hu J, Lin J, Sun D, Xiong Z, Gu X, Hao K, et al. SHANK3 Co-ordinately Regulates Autophagy and Apoptosis in Myocardial Infarction. Front Physiol. 2020;11:1082. doi:3389/fphys.2020.01082

47. Refaat MM, Aouizerat BE, Pullinger CR, Malloy M, Kane J, Tseng ZH. Association of CASQ2 polymorphisms with sudden cardiac arrest and heart failure in patients with coronary artery disease. Heart Rhythm. 2014;11(4):646-652. doi:1016/j.hrthm.2014.01.015

48. Pritchard AB, Kanai SM, Krock B, Schindewolf E, Oliver-Krasinski J, Khalek N, Okashah N, Lambert NA, Tavares ALP, Zackai E, et al. Loss-of-function of Endothelin receptor type A results in Oro-OtoCardiac syndrome. Am J Med Genet A. 2020;182(5):1104-1116. doi:1002/ajmg.a.61531

49. Yang D, Jin C, Ma H, Huang M, Shi GP, Wang J, Xiang M. EphrinB2/EphB4 pathway in postnatal angiogenesis: a potential therapeutic target for ischemic cardiovascular disease. Angiogenesis. 2016;19(3):297-309. doi:1007/s10456-016-9514-9

50. Jorholt J, Formicheva Y, Vershinina T, Kiselev A, Muravyev A, Demchenko E, Fedotov P, Zlotina A, Rygkov A, Vasichkina E, et al. Cardiomyopathy and Skeletal Muscle Features Associated with ALPK3 Homozygous and Compound Heterozygous Variants. Genes (Basel). 2020;11(10):1201. doi:3390/genes11101201

51. Touma M, Kang X, Gao F, Zhao Y, Cass AA, Biniwale R, Xiao X, Eghbali M, Coppola G, Reemtsen B, et al. Wnt11 regulates cardiac chamber development and disease during perinatal maturation. JCI Insight. 2017;2(17):e94904. doi:1172/jci.insight.94904

52. Liu Z, Zhao N, Zhu H, Zhu S, Pan S, Xu J, Zhang X, Zhang Y, Wang J. Circulating interleukin-1 $\beta$ promotes endoplasmic reticulum stress-induced myocytes apoptosis in diabetic cardiomyopathy via interleukin-1 receptor-associated kinase-2. Cardiovasc Diabetol. 2015;14:125. doi:1186/s12933-0150288-y

53. Barrett PM, Topol EJ. The fibrillin-1 gene: unlocking new therapeutic pathways in cardiovascular disease. Heart. 2013;99(2):83-90. doi:1136/heartjnl-2012-301840

54. Wu Y, Liu X, Zheng H, Zhu H, Mai W, Huang X, Huang Y. Multiple Roles of sFRP2 in Cardiac Development and Cardiovascular Disease. Int J Biol Sci. 2020;16(5):730-738. doi:7150/ijbs.40923

55. Mao Z, Wang Y, Peng H, He F, Zhu L, Huang H, Huang X, Lu X, Tan X. A newly identified missense mutation in CLCA2 is associated with autosomal dominant cardiac conduction block. Gene. 2019;714:143990. doi:1016/j.gene.2019.143990

56. Wu C, Yan H, Sun J, Yang F, Song C, Jiang F, Li Y, Dong J, Zheng GY, Tian XL, et al. NEXN is a novel susceptibility gene for coronary artery disease in Han Chinese. PLoS One. 2013;8(12):e82135. doi:1371/journal.pone.0082135

57. Hoke M, Schillinger M, Dick P, Exner M, Koppensteiner R, Minar E, Mlekusch W, Schlager O, Wagner O, Mannhalter $\mathrm{C}$. Polymorphism of the palladin gene and cardiovascular outcome in patients with atherosclerosis. Eur J Clin Invest. 2011;41(4):365-371. doi:1111/j.1365-2362.2010.02416.x

58. Wang Y, Wang Y, Adi D, He X, Liu F, Abudesimu A, Fu Z, Ma Y.Dab2 gene variant is associated with increased coronary artery disease risk in Chinese Han population. Medicine (Baltimore). 
2020;99(27):e20924. doi:1097/MD.0000000000020924

59. Harman JL, Sayers J, Chapman C, Pellet-Many C. Emerging Roles for Neuropilin-2 in Cardiovascular Disease. Int J Mol Sci. 2020;21(14):5154. doi:3390/ijms21145154

60. Wang Y, Fu W, Xie F, Wang Y, Chu X, Wang H, Shen M, Wang Y, Wang Y, Sun W, L, et al. Common polymorphisms in ITGA2, PON1 and THBS2 are associated with coronary atherosclerosis in a candidate gene association study of the Chinese Han population. J Hum Genet. 2010;55(8):490-494. doi:1038/jhg.2010.53

61. Wei Y, Zhu M, Corbalán-Campos J, Heyll K, Weber C, Schober A. Regulation of Csf1r and Bcl6 in macrophages mediates the stage-specific effects of microRNA-155 on atherosclerosis. Arterioscler Thromb Vasc Biol. 2015;35(4):796-803. doi:1161/ATVBAHA.114.304723

62. Long QQ, Wang H, Gao W, Fan Y, Li YF, Ma Y, Yang Y, Shi HJ, Chen BR, Meng HY, e4t al. Long Noncoding RNA Kcna2 Antisense RNA Contributes to Ventricular Arrhythmias via Silencing Kcna2 in Rats With Congestive Heart Failure. J Am Heart Assoc. 2017;6(12):e005965. doi:1161/JAHA.117.005965

63. Beitelshees AL, Navare H, Wang D, Gong Y, Wessel J, Moss JI, Langaee TY, Cooper-DeHoff RM, Sadee W, Pepine CJ, et al. CACNA1C gene polymorphisms, cardiovascular disease outcomes, and treatment response. Circ Cardiovasc Genet. 2009;2(4):362-370. doi:1161/CIRCGENETICS.109.857839

64. Gigante B, Vikström M, Meuzelaar LS, Chernogubova E, Silveira A, Hooft FV, Hamsten A, de Faire U. Variants in the coagulation factor 2 receptor (F2R) gene influence the risk of myocardial infarction in men through an interaction with interleukin 6 serum levels. Thromb Haemost. 2009;101(5):943-953.

65. Lei Q, Yi T, Li H, Yan Z, Lv Z, Li G, Wang Y. Ubiquitin C-terminal hydrolase L1 (UCHL1) regulates postmyocardial infarction cardiac fibrosis through glucose-regulated protein of $78 \mathrm{kDa}$ (GRP78). Sci Rep. 2020;10(1):10604. doi:1038/s41598-020-67746-4

66. de Jager SC, Bongaerts BW, Weber M, Kraaijeveld AO, Rousch M, Dimmeler S, van Dieijen-Visser MP, Cleutjens KB, Nelemans PJ, van Berkel TJ, et al. Chemokines CCL3/MIP1a, CCL5/RANTES and CCL18/PARC are independent risk predictors of short-term mortality in patients with acute coronary syndromes. PLoS One. 2012;7(9):e45804. doi:1371/journal.pone.0045804

67. Ruppert V, Meyer T, Richter A, Maisch B, Pankuweit S; German Competence Network of Heart Failure. Identification of a missense mutation in the melusin-encoding ITGB1BP2 gene in a patient with dilated cardiomyopathy. Gene. 2013;512(2):206-210. doi:1016/j.gene.2012.10.055

68. Andenæs K, Lunde IG, Mohammadzadeh N, Dahl CP, Aronsen JM, Strand ME, Palmero S, Sjaastad I, Christensen G, Engebretsen KVT, et al. The extracellular matrix proteoglycan fibromodulin is upregulated in clinical and experimental heart failure and affects cardiac remodeling. PLoS One. 2018;13(7):e0201422. doi:1371/journal.pone.0201422

69. Hu Z, Xiao X, Zhang Z, Li M. Genetic insights and neurobiological implications from NRXN1 in neuropsychiatric disorders. Mol Psychiatry. 2019;24(10):1400-1414. doi:1038/s41380-019-0438-9

70. Liu Z, Liu W, Yao L, Yang C, Xiao L, Wan Q, Gao K, Wang H, Zhu F, Wang G et al. Negative life events and corticotropin-releasing-hormone receptor1 gene in recurrent major depressive disorder. Sci Rep. 
2013;3:1548. doi:1038/srep01548

71. Eltokhi A, Rappold G, Sprengel R. Distinct Phenotypes of Shank2 Mouse Models Reflect Neuropsychiatric Spectrum Disorders of Human Patients With SHANK2 Variants. Front Mol Neurosci. 2018;11:240. doi:3389/fnmol.2018.00240

72. Cai Y, An SS, Kim S. Mutations in presenilin 2 and its implications in Alzheimer's disease and other dementia-associated disorders. Clin Interv Aging. 2015;10:1163-1172. doi:2147/CIA.S85808

73. Pfeiffer FE, Homburger HA, Houser OW, Baker HL Jr, Yanagihara T. Elevation of serum creatine kinase B-subunit levels by radiographic contrast agents in patients with neurologic disorders. Mayo Clin Proc. 1987;62(5):351-357. doi:1016/s0025-6196(12)65438-x

74. Lin S, He L, Shen R, Fang F, Pan H, Zhu X, Wang M, Zhou Z, Liu Z, Wang X, et al. Identification of the CD200R1 promoter and the association of its polymorphisms with the risk of Parkinson's disease. Eur J Neurol. 2020;27(7):1224-1230. doi:1111/ene.14224

75. Royer-Zemmour B, Ponsole-Lenfant M, Gara H, Roll P, Lévêque C, Massacrier A, Ferracci G, Cillario J, Robaglia-Schlupp A, Vincentelli R, et al. Epileptic and developmental disorders of the speech cortex: ligand/receptor interaction of wild-type and mutant SRPX2 with the plasminogen activator receptor uPAR. Hum Mol Genet. 2008;17(23):3617-3630. doi:1093/hmg/ddn256

76. Pastor M, Fernández-Calle R, Di Geronimo B, Vicente-Rodríguez M, Zapico JM, Gramage E, Coderch C, Pérez-García C, Lasek AW, Puchades-Carrasco L, et al. Development of inhibitors of receptor protein tyrosine phosphatase $\beta / \zeta$ (PTPRZ1) as candidates for CNS disorders. Eur J Med Chem. 2018;144:318-329. doi:1016/j.ejmech.2017.11.080

77. Goodspeed K, Pérez-Palma E, Iqbal S, Cooper D, Scimemi A, Johannesen KM, Stefanski A, Demarest $\mathrm{S}$, Helbig KL, Kang J, et al. Current knowledge of SLC6A1-related neurodevelopmental disorders. Brain Commun. 2020;2(2):fcaa170. doi:1093/braincomms/fcaa170

78. Zhang T, Li J, Yu H, Shi Y, Li Z, Wang L, Wang Z, Lu T, Wang L, Yue W, et al. Meta-analysis of GABRB2 polymorphisms and the risk of schizophrenia combined with GWAS data of the Han Chinese population and psychiatric genomics consortium. PLoS One. 2018;13(6):e0198690. doi:1371/journal.pone. 0198690

79. Rogers A, Golumbek P, Cellini E, Doccini V, Guerrini R, Wallgren-Pettersson C, Thuresson AC, Gurnett CA. De novo KCNA1 variants in the PVP motif cause infantile epileptic encephalopathy and cognitive impairment similar to recurrent KCNA2 variants. Am J Med Genet A. 2018;176(8):1748-1752. doi:1002/ajmg.a.38840

80. Su Y, Yang L, Li Z, Wang W, Xing M, Fang Y, Cheng Y, Lin GN, Cui D. The interaction of ASAH1 and NGF gene involving in neurotrophin signaling pathway contributes to schizophrenia susceptibility and psychopathology. Prog Neuropsychopharmacol Biol Psychiatry. 2021;104:110015. doi:1016/j.pnpbp.2020.110015

81. Foale S, Berry M, Logan A, Fulton D, Ahmed Z. LINGO-1 and AMIGO3, potential therapeutic targets for neurological and dysmyelinating disorders?. Neural Regen Res. 2017;12(8):1247-1251. doi:4103/1673-5374.213538 
82. Ravichandran S, Finlin BS, Kern PA, Özcan S. Sphk2-/- mice are protected from obesity and insulin resistance. Biochim Biophys Acta Mol Basis Dis. 2019;1865(3):570-576.

doi:1016/j.bbadis.2018.12.012

83. Labonté ED, Camarota LM, Rojas JC, Jandacek RJ, Gilham DE, Davies JP, loannou YA, Tso P, Hui DY, Howles PN. Reduced absorption of saturated fatty acids and resistance to diet-induced obesity and diabetes by ezetimibe-treated and Npc1/1-/- mice. Am J Physiol Gastrointest Liver Physiol. 2008;295(4):G776-G783. doi:1152/ajpgi.90275.2008

84. Watt MJ, Dzamko N, Thomas WG, Rose-John S, Ernst M, Carling D, Kemp BE, Febbraio MA, Steinberg GR. CNTF reverses obesity-induced insulin resistance by activating skeletal muscle AMPK. Nat Med. 2006;12(5):541-548. doi:1038/nm1383

85. Yang Q, Graham TE, Mody N, Preitner F, Peroni OD, Zabolotny JM, Kotani K, Quadro L, Kahn BB. Serum retinol binding protein 4 contributes to insulin resistance in obesity and type 2 diabetes. Nature. 2005;436(7049):356-362. doi:1038/nature03711

86. Awazawa M, Gabel P, Tsaousidou E, Nolte H, Krüger M, Schmitz J, Ackermann PJ, Brandt C, Altmüller $\mathrm{J}$, Motameny $\mathrm{S}$, et al. A microRNA screen reveals that elevated hepatic ectodysplasin A expression contributes to obesity-induced insulin resistance in skeletal muscle. Nat Med. 2017;23(12):14661473. doi: $1038 / \mathrm{nm} .4420$

87. Ludvigsen TP, Olsen LH, Pedersen HD, Christoffersen BØ, Jensen LJ. Hyperglycemia-induced transcriptional regulation of ROCK1 and TGM2 expression is involved in small artery remodeling in obese diabetic Göttingen Minipigs. Clin Sci (Lond). 2019;133(24):2499-2516. doi:1042/CS20191066

88. Cockburn BN, Ostrega DM, Sturis J, Kubstrup C, Polonsky KS, Bell GI. Changes in pancreatic islet glucokinase and hexokinase activities with increasing age, obesity, and the onset of diabetes. Diabetes. 1997;46(9):1434-1439. doi:2337/diab.46.9.1434

89. Berndt J, Kovacs P, Ruschke K, Klöting N, Fasshauer M, Schön MR, Körner A, Stumvoll M, Blüher M. Fatty acid synthase gene expression in human adipose tissue: association with obesity and type 2 diabetes. Diabetologia. 2007;50(7):1472-1480. doi:1007/s00125-007-0689-x

90. Williams KH, Viera de Ribeiro AJ, Prakoso E, Veillard AS, Shackel NA, Bu Y, Brooks B, Cavanagh E, Raleigh $\mathrm{J}$, et al. Lower serum fibroblast activation protein shows promise in the exclusion of clinically significant liver fibrosis due to non-alcoholic fatty liver disease in diabetes and obesity. Diabetes Res Clin Pract. 2015;108(3):466-472. doi:1016/j.diabres.2015.02.024

91. de Brito G, Lupinacci FC, Beraldo FH, Santos TG, Roffé M, Lopes MH, de Lima VC, Martins VR, Hajj GN. Loss of prion protein is associated with the development of insulin resistance and obesity. Biochem J. 2017;474(17):2981-2991. doi:1042/BCJ20170137

92. Michurina SV, Ishchenko IY, Arkhipov SA, Klimontov VV, Rachkovskaya LN, Konenkov VI, Zavyalov EL. Effects of Melatonin, Aluminum Oxide, and Polymethylsiloxane Complex on the Expression of LYVE1 in the Liver of Mice with Obesity and Type 2 Diabetes Mellitus. Bull Exp Biol Med. 2016;162(2):269272. doi:1007/s10517-016-3592-y 
93. Kaur P, Reis MD, Couchman GR, Forjuoh SN, Greene JF, Asea A. SERPINE 1 Links Obesity and Diabetes: A Pilot Study. J Proteomics Bioinform. 2010;3(6):191-199. doi:4172/jpb.1000139

94. Serino M, Menghini R, Fiorentino L, Amoruso R, Mauriello A, Lauro D, Sbraccia P, Hribal ML, Lauro R, Federici M. Mice heterozygous for tumor necrosis factor-alpha converting enzyme are protected from obesity-induced insulin resistance and diabetes. Diabetes. 2007;56(10):2541-2546. doi:2337/db070360

95. Blüher M, Klöting N, Wueest S, Schoenle EJ, Schön MR, Dietrich A, Fasshauer M, Stumvoll M, Konrad D. Fas and FasL expression in human adipose tissue is related to obesity, insulin resistance, and type 2 diabetes. J Clin Endocrinol Metab. 2014;99(1):E36-E44. doi:1210/jc.2013-2488

96. Muratsu J, Iwabayashi M, Sanada F, Taniyama Y, Otsu R, Rakugi H, Morishita R. Hepatocyte Growth Factor Prevented High-Fat Diet-Induced Obesity and Improved Insulin Resistance in Mice. Sci Rep. 2017;7(1):130. doi:1038/s41598-017-00199-4

97. Xiong XQ, Geng Z, Zhou B, Zhang F, Han Y, Zhou YB, Wang JJ, Gao XY, Chen Q, Li YH, et al. FNDC5 attenuates adipose tissue inflammation and insulin resistance via AMPK-mediated macrophage polarization in obesity. Metabolism. 2018;83:31-41. doi:1016/j.metabol.2018.01.013

98. Kim KE, Cho YS, Baek KS, Li L, Baek KH, Kim JH, Kim HS, Sheen YH. Lipopolysaccharide-binding protein plasma levels as a biomarker of obesity-related insulin resistance in adolescents. Korean J Pediatr. 2016;59(5):231-238. doi:3345/kjp.2016.59.5.231

99. Daley EJ, Pajevic PD, Roy S, Trackman PC. Impaired Gastric Hormone Regulation of Osteoblasts and Lysyl Oxidase Drives Bone Disease in Diabetes Mellitus. JBMR Plus. 2019;3(10):e10212. . doi:1002/jbm4.10212

100. Hirai H, Miura J, Hu Y, Larsson H, Larsson K, Lernmark A, Ivarsson SA, Wu T, Kingman A, Tzioufas AG, et al. Selective screening of secretory vesicle-associated proteins for autoantigens in type 1 diabetes: VAMP2 and NPY are new minor autoantigens. Clin Immunol. 2008;127(3):366-374. doi:1016/j.clim.2008.01.018

101. Vuori N, Sandholm N, Kumar A, Hietala K, Syreeni A, Forsblom C, Juuti-Uusitalo K, Skottman H, Imamura M, Maeda S, et al. CACNB2 Is a Novel Susceptibility Gene for Diabetic Retinopathy in Type 1 Diabetes. Diabetes. 2019;68(11):2165-2174. doi:2337/db19-0130

102. Porta M, Toppila I, Sandholm N, Hosseini SM, Forsblom C, Hietala K, Borio L, Harjutsalo V, Klein BE, Klein R, et al. Variation in SLC19A3 and Protection From Microvascular Damage in Type 1 Diabetes. Diabetes. 2016;65(4):1022-1030. doi:2337/db15-1247

103. Nomoto H, Pei L, Montemurro C, Rosenberger M, Furterer A, Coppola G, Nadel B, Pellegrini M, Gurlo T, Butler PC, et al. Activation of the HIF1a/PFKFB3 stress response pathway in beta cells in type 1 diabetes. Diabetologia. 2020;63(1):149-161. doi:1007/s00125-019-05030-5

104. Blindbæk SL, Schlosser A, Green A, Holmskov U, Sorensen GL, Grauslund J. Association between microfibrillar-associated protein 4 (MFAP4) and micro- and macrovascular complications in longterm type 1 diabetes mellitus. Acta Diabetol. 2017;54(4):367-372. doi:1007/s00592-016-0953-y 
105. Hu Z, Liu F, Li M, He J, Huang J, Rao DC, Hixson JE, Gu C, Kelly TN, Chen S, et al. Associations of Variants in the CACNA1A and CACNA1C Genes With Longitudinal Blood Pressure Changes and Hypertension Incidence: The GenSalt Study. Am J Hypertens. 2016;29(11):1301-1306. doi:1093/ajh/hpw070

106. Tabbò F, D'Aveni A, Tota D, Pignataro D, Bironzo P, Carnio S, Cappia S, Cortese G, Righi L, Novello S. Pulmonary Arterial Hypertension in ALK Receptor Tyrosine Kinase-Positive Lung Cancer Patient: Adverse Event or Disease Spread?. J Thorac Oncol. 2019;14(2):e38-e40. doi:1016/j.jtho.2018.10.154

107. Yang HC, Liang YJ, Chen JW, Chiang KM, Chung CM, Ho HY, Ting CT, Lin TH, Sheu SH, Tsai WC, et al. Identification of IGF1, SLC4A4, WWOX, and SFMBT1 as hypertension susceptibility genes in Han Chinese with a genome-wide gene-based association study. PLoS One. 2012;7(3):e32907. doi:1371/journal.pone.0032907

108. Erlandsson L, Ducat A, Castille J, Zia I, Kalapotharakos G, Hedström E, Vilotte JL, Vaiman D, Hansson SR. Ipha-1 microglobulin as a potential therapeutic candidate for treatment of hypertension and oxidative stress in the STOX1 preeclampsia mouse model. Sci Rep. 2019;9(1):8561. doi:1038/s41598-019-44639-9

109. Samokhin AO, Stephens T, Wertheim BM, Wang RS, Vargas SO, Yung LM, Cao M, Brown M, Arons E, Dieffenbach PB, et al. NEDD9 targets COL3A1 to promote endothelial fibrosis and pulmonary arterial hypertension. Sci Transl Med. 2018;10(445):eaap7294. doi:1126/scitranslmed.aap7294

110. Fava C, Montagnana M, Danese E, Sjögren M, Almgren P, Engström G, Hedblad B, Guidi GC, Minuz P, Melander 0. Vanin-1 T26I polymorphism, hypertension and cardiovascular events in two large urbanbased prospective studies in Swedes. Nutr Metab Cardiovasc Dis. 2013;23(1):53-60. doi:1016/j.numecd.2011.01.012

111. Wang L, Li H, Yang B, Guo L, Han X, Li L, Li M, Huang J, Gu D. The Hypertension Risk Variant Rs820430 Functions as an Enhancer of SLC4A7. Am J Hypertens. 2017;30(2):202-208. doi:1093/ajh/hpw127.

112. Bhupatiraju C, Patkar S, Pandharpurkar D, Joshi S, Tirunilai P. Association and interaction of $-58 C>T$ and \pm 9 bp polymorphisms of BDKRB2 gene causing susceptibility to essential hypertension. Clin Exp Hypertens. 2012;34(3):230-235. doi:3109/10641963.2011.631653

113. Zhang H, Sun ZQ, Liu SS, Yang LN. Association between GRK4 and DRD1 gene polymorphisms and hypertension: a meta-analysis. Clin Interv Aging. 2015;11:17-27. doi:2147/CIA.S94510

114. Xu K, Ma L, Li Y, Wang F, Zheng GY, Sun Z, Jiang F, Chen Y, Liu H, Dang A, et al. Genetic and Functional Evidence Supports LPAR1 as a Susceptibility Gene for Hypertension. Hypertension. 2015;66(3):641-646. doi:1161/HYPERTENSIONAHA.115.05515

115. Lee SM, Baik J, Nguyen D, Nguyen V, Liu S, Hu Z, Abbott GW. Kcne2 deletion impairs insulin secretion and causes type 2 diabetes mellitus. FASEB J. 2017;31(6):2674-2685. doi:1096/fj.201601347

116. Deng Z, Shen J, Ye J, Shu Q, Zhao J, Fang M, Zhang T. Association between single nucleotide polymorphisms of delta/notch-like epidermal growth factor (EGF)-related receptor (DNER) and Delta- 
like 1 Ligand (DLL 1) with the risk of type 2 diabetes mellitus in a Chinese Han population. Cell Biochem Biophys. 2015;71(1):331-335. doi:1007/s12013-014-0202-3

117. Emdin CA, Khera AV, Aragam K, Haas M, Chaffin M, Klarin D, Natarajan P, Bick A, Zekavat SM, Nomura $A$, et al. DNA Sequence Variation in ACVR1C Encoding the Activin Receptor-Like Kinase 7 Influences Body Fat Distribution and Protects Against Type 2 Diabetes. Diabetes. 2019;68(1):226-234. doi:2337/db18-0857

118. Kim KS, Jung Yang H, Lee IS, Kim KH, Park J, Jeong HS, Kim Y, Seok Ahn K, et al. The aglycone of ginsenoside Rg3 enables glucagon-like peptide-1 secretion in enteroendocrine cells and alleviates hyperglycemia in type 2 diabetic mice. Sci Rep. 2015;5:18325. doi:1038/srep18325

119. Mtiraoui N, Turki A, Nemr R, Echtay A, Izzidi I, Al-Zaben GS, Irani-Hakime N, Keleshian SH, Mahjoub T, Almawi WY. Contribution of common variants of ENPP1, IGF2BP2, KCNJ11, MLXIPL, PPARY, SLC30A8 and TCF7L2 to the risk of type 2 diabetes in Lebanese and Tunisian Arabs. Diabetes Metab. 2012;38(5):444-449. doi:1016/j.diabet.2012.05.002

120. Ishii $H$, Niiya $T$, Ono $Y$, Inaba $N$, Jinnouchi $H$, Watada $H$. Improvement of quality of life through glycemic control by liraglutide, a GLP-1 analog, in insulin-naive patients with type 2 diabetes mellitus: the PAGE1 study. Diabetol Metab Syndr. 2017;9:3. doi:1186/s13098-016-0202-0

121. Jiang YD, Chang YC, Chiu YF, Chang TJ, Li HY, Lin WH, Yuan HY, Chen YT, Chuang LM. SLC2A10 genetic polymorphism predicts development of peripheral arterial disease in patients with type 2 diabetes. SLC2A10 and PAD in type 2 diabetes. BMC Med Genet. 2010;11:126. doi:1186/1471-235011-126

122. Harder MN, Ribel-Madsen R, Justesen JM, Spars $\varnothing$ T, Andersson EA, Grarup N, Jørgensen T, Linneberg A, Hansen T, Pedersen 0. Type 2 diabetes risk alleles near BCAR1 and in ANK1 associate with decreased $\beta$-cell function whereas risk alleles near ANKRD55 and GRB14 associate with decreased insulin sensitivity in the Danish Inter99 cohort. J Clin Endocrinol Metab. 2013;98(4):E801-E806. doi:1210/jc.2012-4169

123. Aruga $\mathrm{M}$, Tokita $\mathrm{Y}$, Nakajima $\mathrm{K}, \mathrm{Kamachi} \mathrm{K}$, Tanaka A. The effect of combined diet and exercise intervention on body weight and the serum GPIHBP1 concentration in overweight/obese middle-aged women. Clin Chim Acta. 2017;475:109-115. doi:1016/j.cca.2017.10.017

124. Baruch A, Wong C, Chinn LW, Vaze A, Sonoda J, Gelzleichter T, Chen S, Lewin-Koh N, Morrow L, Dheerendra S, et al. Antibody-mediated activation of the FGFR1/Klotho $\beta$ complex corrects metabolic dysfunction and alters food preference in obese humans. Proc Natl Acad Sci U S A. 2020;117(46):28992-29000. doi:1073/pnas.2012073117

125. Soussi H, Reggio S, Alili R, Prado C, Mutel S, Pini M, Rouault C, Clément K, Dugail I. DAPK2 Downregulation Associates With Attenuated Adipocyte Autophagic Clearance in Human Obesity. Diabetes. 2015;64(10):3452-3463. doi:2337/db14-1933

126. Haim Y, Blüher M, Konrad D, Goldstein N, Klöting N, Harman-Boehm I, Kirshtein B, Ginsberg D, Tarnovscki T, Gepner Y, et al. ASK1 (MAP3K5) is transcriptionally upregulated by E2F1 in adipose 
tissue in obesity, molecularly defining a human dys-metabolic obese phenotype. Mol Metab. 2017;6(7):725-736. doi:1016/j.molmet.2017.05.003

127. Aliasghari F, Nazm SA, Yasari S, Mahdavi R, Bonyadi M. Associations of the ANKK1 and DRD2 gene polymorphisms with overweight, obesity and hedonic hunger among women from the Northwest of Iran [published online ahead of print, 2020 Feb 4]. Eat Weight Disord. 2020;10.1007/s40519-02000851-5. doi:1007/s40519-020-00851-5

128. Koschinsky T, Gries FA, Herberg L. Regulation of glycerol kinase by insulin in isolated fat cells and liver of Bar Harbor obese mice. Diabetologia. 1971;7(5):316-322. doi:1007/BF01219464

129. Xie J, Shao Y, Liu J, Cui M, Xiao X, Gong J, Xue B, Zhang Q, Hu X, Duan H. K27Q/K29Q mutations in sphingosine kinase 1 attenuate high-fat diet induced obesity and altered glucose homeostasis in mice. Sci Rep. 2020;10(1):20038. doi:1038/s41598-020-77096-w

130. Schwindinger WF, Borrell BM, Waldman LC, Robishaw JD. Mice lacking the G protein gamma3subunit show resistance to opioids and diet induced obesity. Am J Physiol Regul Integr Comp Physiol. 2009;297(5):R1494-R1502. doi:1152/ajpregu.00308.2009

131. Founds SA, Ren D, Roberts JM, Jeyabalan A, Powers RW. Follistatin-like 3 across gestation in preeclampsia and uncomplicated pregnancies among lean and obese women. Reprod Sci. 2015;22(4):402-409. doi:1177/1933719114529372

132. Liu KY, Sengillo JD, Velez G, Jauregui R, Sakai LY, Maumenee IH, Bassuk AG, Mahajan VB, Tsang SH. Missense mutation in SLIT2 associated with congenital myopia, anisometropia, connective tissue abnormalities, and obesity. Orphanet J Rare Dis. 2018;13(1):138. doi:1186/s13023-018-0885-4

133. Osorio-Conles O, Guitart M, Moreno-Navarrete JM, Escoté X, Duran X, Fernandez-Real JM, GomezFoix AM, Fernández-Veledo S, Vendrell J. Adipose tissue and serum CCDC80 in obesity and its association with related metabolic disease. Mol Med. 2017;23:225-234. doi:2119/molmed.2017.00067

134. Dankel SN, Røst TH, Kulyté A, Fandalyuk Z, Skurk T, Hauner H, Sagen JV, Rydén M, Arner P, Mellgren G. The Rho GTPase RND3 regulates adipocyte lipolysis. Metabolism. 2019;101:153999. doi:1016/j.metabol.2019.153999

135. Yasui M, Tamura Y, Minami M, Higuchi S, Fujikawa R, Ikedo T, Nagata M, Arai H, Murayama T, Yokode M. The Prostaglandin E2 Receptor EP4 Regulates Obesity-Related Inflammation and Insulin Sensitivity. PLoS One. 2015;10(8):e0136304. doi:1371/journal.pone.0136304

136. Lu F, Liu Q. Validation of RUNX1 as a potential target for treating circadian clock-induced obesity through preventing migration of group 3 innate lymphoid cells into intestine. Med Hypotheses. 2018;113:98-101. doi:1016/j.mehy.2018.02.015

137. Masaki M, Kurisaki T, Shirakawa K, Sehara-Fujisawa A. Role of meltrin \{alpha\} (ADAM12) in obesity induced by high- fat diet. Endocrinology. 2005;146(4):1752-1763. doi:1210/en.2004-1082

138. Khaidakov M, Mitra S, Kang BY, Wang X, Kadlubar S, Novelli G, Raj V, Winters M, Carter WC, Mehta JL. Oxidized LDL receptor 1 (OLR1) as a possible link between obesity, dyslipidemia and cancer. PLoS One. 2011;6(5):e20277. doi:1371/journal.pone.0020277

Page 22/38 
139. Matsuo Y, Tanaka M, Yamakage H, Sasaki Y, Muranaka K, Hata H, Ikai I, Shimatsu A, Inoue M, Chun $\mathrm{TH}$, et al. Thrombospondin 1 as a novel biological marker of obesity and metabolic syndrome. Metabolism. 2015;64(11):1490-1499. doi:1016/j.metabol.2015.07.016

140. Poggi M, Morin SO, Bastelica D, Govers R, Canault M, Bernot D, Georgelin O, Verdier M, Burcelin R, Olive $D$, et al. CD28 deletion improves obesity-induced liver steatosis but increases adiposity in mice. Int J Obes (Lond). 2015;39(6):977-985. doi:1038/ijo.2015.26

141. Zhu Y, Wen L, Wang S, Zhang K, Cui Y, Zhang C, Feng L, Yu F, Chen Y, Wang R, et al. Omega-3 fatty acids improve flow-induced vasodilation by enhancing TRPV4 in arteries from diet-induced obese mice. Cardiovasc Res. 2020;cvaa296. doi:1093/cvr/cvaa296

142. He L, Gunn TM, Bouley DM, Lu XY, Watson SJ, Schlossman SF, Duke-Cohan JS, Barsh GS. A biochemical function for attractin in agouti-induced pigmentation and obesity. Nat Genet. 2001;27(1):40-47. doi:1038/83741

143. Moreno-Navarrete JM, Ortega F, Gómez-Serrano M, García-Santos E, Ricart W, Tinahones F, Mingrone G, Peral B, Fernández-Real JM. The MRC1/CD68 ratio is positively associated with adipose tissue lipogenesis and with muscle mitochondrial gene expression in humans. PLoS One. 2013;8(8):e70810. doi:1371/journal.pone.0070810

144. Nam JS, Ahn CW, Park HJ, Kim YS. Semaphorin $3 \mathrm{C}$ is a Novel Adipokine Representing ExerciseInduced Improvements of Metabolism in Metabolically Healthy Obese Young Males. Sci Rep. 2020;10(1):10005. doi:1038/s41598-020-67004-7

145. Kwak SH, Park BL, Kim H, German MS, Go MJ, Jung HS, Koo BK, Cho YM, Choi SH, Cho YS, et al. Association of variations in TPH1 and HTR2B with gestational weight gain and measures of obesity. Obesity (Silver Spring). 2012;20(1):233-238. doi:1038/oby.2011.253

146. Muñoz M, López-Oliva ME, Rodríguez C, Martínez MP, Sáenz-Medina J, Sánchez A, Climent B, Benedito S, García-Sacristán A, Rivera L, et al. Differential contribution of Nox1, Nox2 and Nox4 to kidney vascular oxidative stress and endothelial dysfunction in obesity. Redox Biol. 2020;28:101330. doi:1016/j.redox.2019.101330

147. Klöting N, Wilke B, Klöting I. Alleles on rat chromosome 4 (D4Got41-Fabp1/Tacr1) regulate subphenotypes of obesity. Obes Res. 2005;13(3):589-595. doi:1038/oby.2005.63

148. Van Camp JK, De Freitas F, Zegers D, Beckers S, Verhulst SL, Van Hoorenbeeck K, Massa G, Verrijken A, Desager KN, Van Gaal LF, et al. Investigation of common and rare genetic variation in the BAMBI genomic region in light of human obesity. Endocrine. 2016;52(2):277-286. doi:1007/s12020-0150778-4

149. Zhang ZB, Ruan CC, Lin JR, Xu L, Chen XH, Du YN, Fu MX, Kong LR, Zhu DL, Gao PJ. Perivascular Adipose Tissue-Derived PDGF-D Contributes to Aortic Aneurysm Formation During Obesity. Diabetes. 2018;67(8):1549-1560. doi:2337/db18-0098

150. Suriyaprom K, Pheungruang B, Tungtrongchitr R, Sroijit OY. Relationships of apelin concentration and APLN T-1860C polymorphism with obesity in Thai children. BMC Pediatr. 2020;20(1):455. doi:1186/s12887-020-02350-z 
151. Vaittinen $M$, Kolehmainen $M$, Rydén $M$, Eskelinen $M$, Wabitsch $M$, Pihlajamäki J, Uusitupa $M$, Pulkkinen L. MFAP5 is related to obesity-associated adipose tissue and extracellular matrix remodeling and inflammation. Obesity (Silver Spring). 2015;23(7):1371-1378. doi:1002/oby.21103

152. Wolff G, Taranko AE, Meln I, Weinmann J, Sijmonsma T, Lerch S, Heide D, Billeter AT, Tews D, Krunic $D$, et al. Diet-dependent function of the extracellular matrix proteoglycan Lumican in obesity and glucose homeostasis. Mol Metab. 2019;19:97-106. doi:1016/j.molmet.2018.10.007

153. Soomro I, Hong A, Li Z, Duncan JS, Skolnik EY. Discoidin Domain Receptor 1 (DDR1) tyrosine kinase is upregulated in PKD kidneys but does not play a role in the pathogenesis of polycystic kidney disease. PLoS One. 2019;14(7):e0211670. doi:1371/journal.pone.0211670

154. Zeng H, Qi X, Xu X, Wu Y. TAB1 regulates glycolysis and activation of macrophages in diabetic nephropathy. Inflamm Res. 2020;69(12):1215-1234. doi:1007/s00011-020-01411-4

155. Zalli D, Bayliss R, Fry AM. The Nek8 protein kinase, mutated in the human cystic kidney disease nephronophthisis, is both activated and degraded during ciliogenesis. Hum Mol Genet. 2012;21(5):1155-1171. doi:1093/hmg/ddr544

156. Li YB, Wu Q, Liu J, Fan YZ, Yu KF, Cai Y. miR-199a-3p is involved in the pathogenesis and progression of diabetic neuropathy through downregulation of SerpinE2. Mol Med Rep. 2017;16(3):2417-2424. doi:3892/mmr.2017.6874

157. Zhou XJ, Cheng FJ, Qi YY, Zhao YF, Hou P, Zhu L, Lv JC, Zhang H. FCGR2B and FCRLB gene polymorphisms associated with IgA nephropathy. PLoS One. 2013;8(4):e61208. doi:1371/journal.pone.0061208

158. Tsai YC, Kuo PL, Hung WW, Wu LY, Wu PH, Chang WA, Kuo MC, Hsu YL. Angpt2 Induces Mesangial Cell Apoptosis through the MicroRNA-33-5p-SOCS5 Loop in Diabetic Nephropathy. Mol Ther Nucleic Acids. 2018;13:543-555. doi:10.1016/j.omtn.2018.10.003

159. Ohtsubo H, Okada T, Nozu K, Takaoka Y, Shono A, Asanuma K, Zhang L, Nakanishi K, TaniguchiIkeda $\mathrm{M}$, Kaito $\mathrm{H}$, et al. Identification of mutations in FN1 leading to glomerulopathy with fibronectin deposits. Pediatr Nephrol. 2016;31(9):1459-1467. doi:1007/s00467-016-3368-7

160. Gerarduzzi C, Kumar RK, Trivedi P, Ajay AK, lyer A, Boswell S, Hutchinson JN, Waikar SS, Vaidya VS. Silencing SMOC2 ameliorates kidney fibrosis by inhibiting fibroblast to myofibroblast transformation. JCI Insight. 2017;2(8):e90299. doi:1172/jci.insight.90299

161. Kim JM, Wu H, Green G, Winkler CA, Kopp JB, Miner JH, Unanue ER, Shaw AS. CD2-associated protein haploinsufficiency is linked to glomerular disease susceptibility. Science. 2003;300(5623):1298-1300. doi:1126/science.1081068

162. Li QS, Cheng P, Favis R, Wickenden A, Romano G, Wang H. SCN9A Variants May be Implicated in Neuropathic Pain Associated With Diabetic Peripheral Neuropathy and Pain Severity. Clin J Pain. 2015;31(11):976-982. doi:1097/AJP.0000000000000205

163. Bennett CE, Nsengimana J, Bostock JA, Cymbalista C, Futers TS, Knight BL, McCormack LJ, Prasad UK, Riches K, Rolton D, et al. CCAAT/enhancer binding protein alpha, beta and delta gene variants: 
associations with obesity related phenotypes in the Leeds Family Study. Diab Vasc Dis Res. 2010;7(3):195-203. doi:1177/1479164110366274

164. Domingues-Montanari S, Subirana I, Tomás M, Marrugat J, Sentí M. Association between ESR2 genetic variants and risk of myocardial infarction. Clin Chem. 2008;54(7):1183-1189. doi:1373/clinchem.2007.102400

165. Eberlé $D$, Clément K, Meyre $D$, Sahbatou $M$, Vaxillaire $M$, Le Gall A, Ferré $P$, Basdevant A, Froguel $P$, Foufelle F. SREBF-1 gene polymorphisms are associated with obesity and type 2 diabetes in French obese and diabetic cohorts. Diabetes. 2004;53(8):2153-2157. doi:2337/diabetes.53.8.2153

166. Cheng J, Song J, He X, Zhang M, Hu S, Zhang S, Yu Q, Yang P, Xiong F, Wang DW, et al. Loss of Mbd2 Protects Mice Against High-Fat Diet-Induced Obesity and Insulin Resistance by Regulating the Homeostasis of Energy Storage and Expenditure. Diabetes. 2016;65(11):3384-3395. doi:2337/db160151

167. Cavallari JF, Fullerton MD, Duggan BM, Foley KP, Denou E, Smith BK, Desjardins EM, Henriksbo BD, Kim KJ, Tuinema BR, et al. Muramyl Dipeptide-Based Postbiotics Mitigate Obesity-Induced Insulin Resistance via IRF4. Cell Metab. 2017;25(5):1063-1074.e3. doi:1016/j.cmet.2017.03.021

168. Qi L, Saberi M, Zmuda E, Wang Y, Altarejos J, Zhang X, Dentin R, Hedrick S, Bandyopadhyay G, Hai T, et al. Adipocyte CREB promotes insulin resistance in obesity. Cell Metab. 2009;9(3):277-286. doi:1016/j.cmet.2009.01.006

169. Yan X, Zhu MJ, Xu W, Tong JF, Ford SP, Nathanielsz PW, Du M. Up-regulation of Toll-like receptor 4/nuclear factor-kappaB signaling is associated with enhanced adipogenesis and insulin resistance in fetal skeletal muscle of obese sheep at late gestation. Endocrinology. 2010;151(1):380-387. doi:1210/en.2009-0849

170. Matsha TE, Kengne AP, Hector S, Mbu DL, Yako YY, Erasmus RT. MicroRNA profiling and their pathways in South African individuals with prediabetes and newly diagnosed type 2 diabetes mellitus. Oncotarget. 2018;9(55):30485-30498. doi:18632/oncotarget.25271

171. Ding L, Ai D, Wu R, Zhang T, Jing L, Lu J, Zhong L. Identification of the differential expression of serum microRNA in type 2 diabetes. Biosci Biotechnol Biochem. 2016;80(3):461-465. doi:1080/09168451.2015.1107460

172. Hall CL, Akhtar MM, Sabater-Molina M, Futema M, Asimaki A, Protonotarios A, Dalageorgou C, Pittman AM, Suarez MP, Aguilera B, et al. Filamin C variants are associated with a distinctive clinical and immunohistochemical arrhythmogenic cardiomyopathy phenotype. Int J Cardiol. 2020;307:101108. doi:1016/j.ijcard.2019.09.048

173. Salazar-Mendiguchía J, Ochoa JP, Palomino-Doza J, Domínguez F, Díez-López C, Akhtar M, RamiroLeón S, Clemente MM, Pérez-Cejas A, Robledo M, et al. Mutations in TRIM63 cause an autosomalrecessive form of hypertrophic cardiomyopathy. Heart. 2020;106(17):1342-1348. doi:1136/heartjnl2020-316913

174. Xiao Y, Deng Y, Yuan F, Xia T, Liu H, Li Z, Chen S, Liu Z, Ying H, Liu Y, et al. An ATF4-ATG5 signaling in hypothalamic POMC neurons regulates obesity. Autophagy. 2017;13(6):1088-1089. 
doi:1080/15548627.2017.1307488

175. Stratigopoulos G, LeDuc CA, Cremona ML, Chung WK, Leibel RL. Cut-like homeobox 1 (CUX1) regulates expression of the fat mass and obesity-associated and retinitis pigmentosa GTPase regulator-interacting protein-1-like (RPGRIP1L) genes and coordinates leptin receptor signaling. J Biol Chem. 2011;286(3):2155-2170. doi:1074/jbc.M110.188482

176. Zhou JP, Ren YD, Xu QY, Song Y, Zhou F, Chen MY, Liu JJ, Chen LG, Pan JS. Obesity-Induced Upregulation of ZBTB7A Promotes Lipid Accumulation through SREBP1. Biomed Res Int. 2020;2020:4087928. doi:1155/2020/4087928

\section{Tables}

Due to technical limitations, table 1-7 is only available as a download in the Supplemental Files section.

\section{Figures}
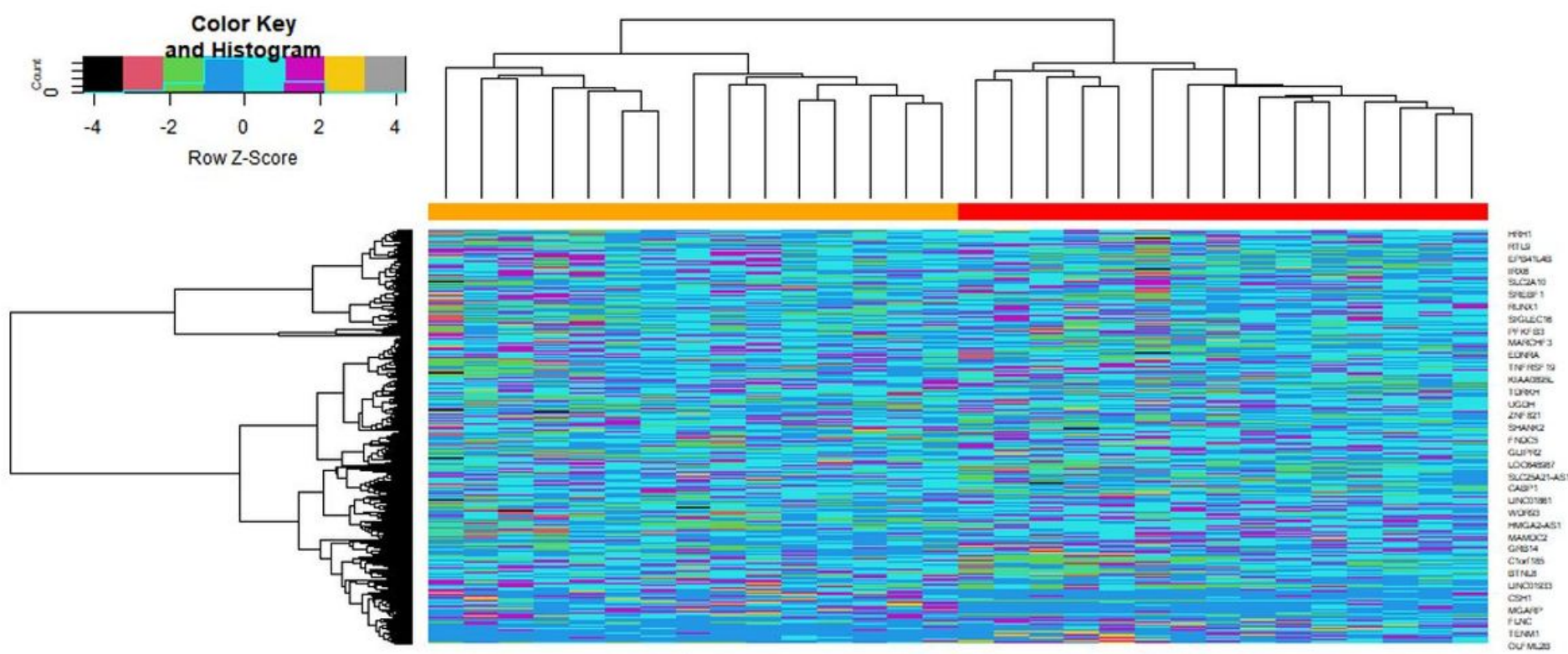

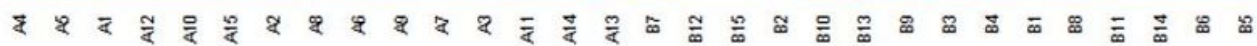

\section{Figure 1}

Heat map of differentially expressed genes. Legend on the top left indicate log fold change of genes. (A1 - A15 = metabolically healthy obese samples; B1 - B15 = metabolically unhealthy obese samples) 


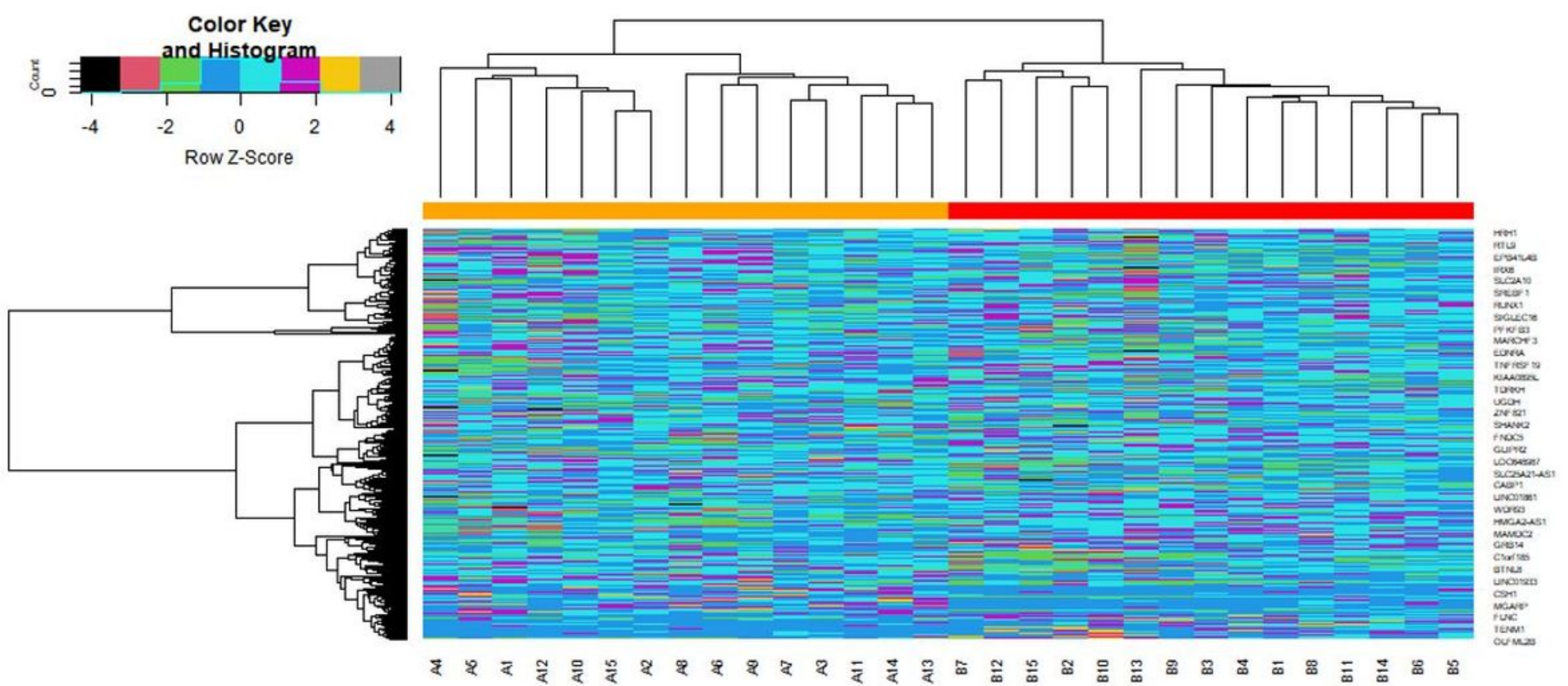

\section{Figure 1}

Heat map of differentially expressed genes. Legend on the top left indicate log fold change of genes. (A1 - A15 = metabolically healthy obese samples; B1 - B15 = metabolically unhealthy obese samples)

\section{Volcano plot}

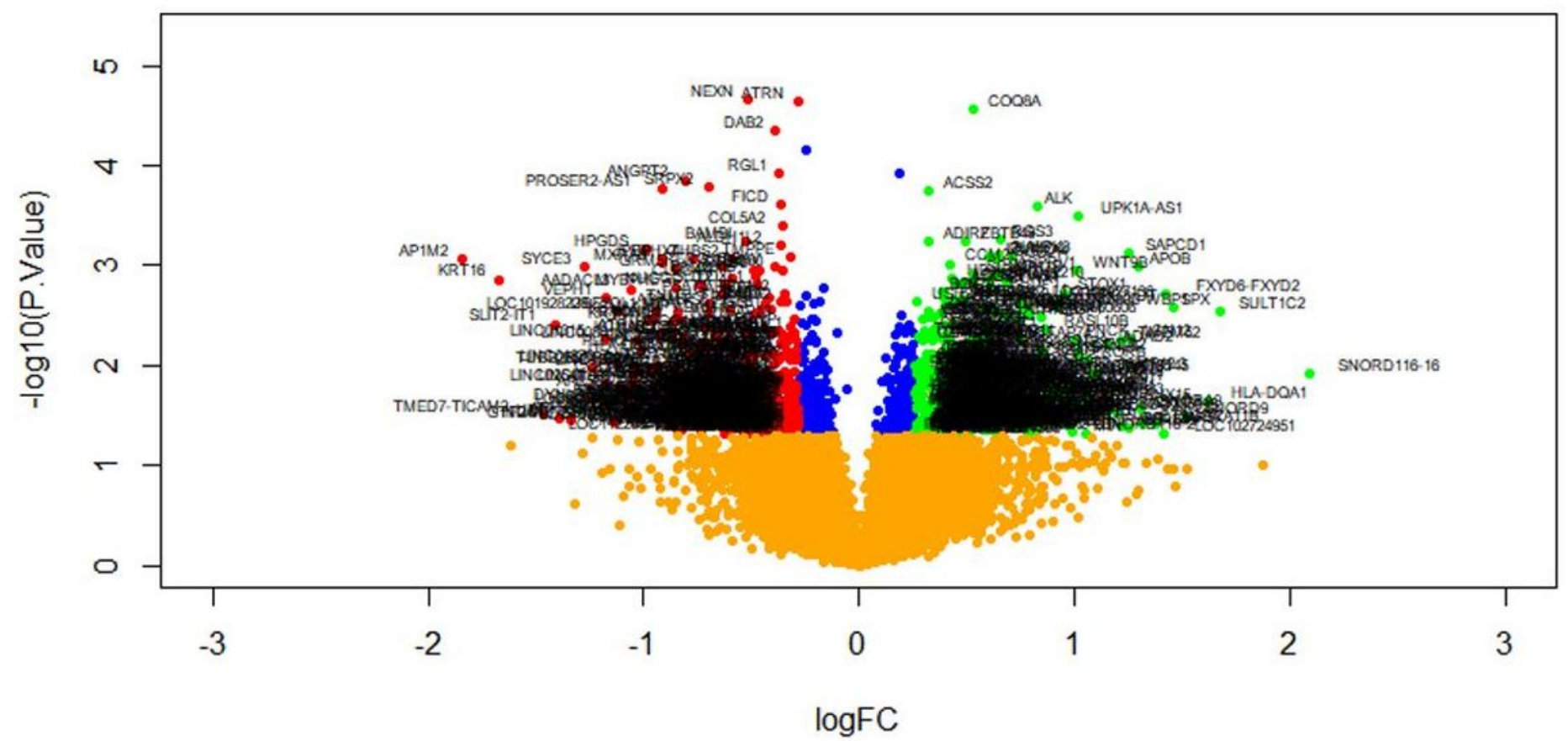

Figure 2 
Volcano plot of differentially expressed genes. Genes with a significant change of more than two-fold were selected. Green dot represented up regulated significant genes and red dot represented down regulated significant genes.

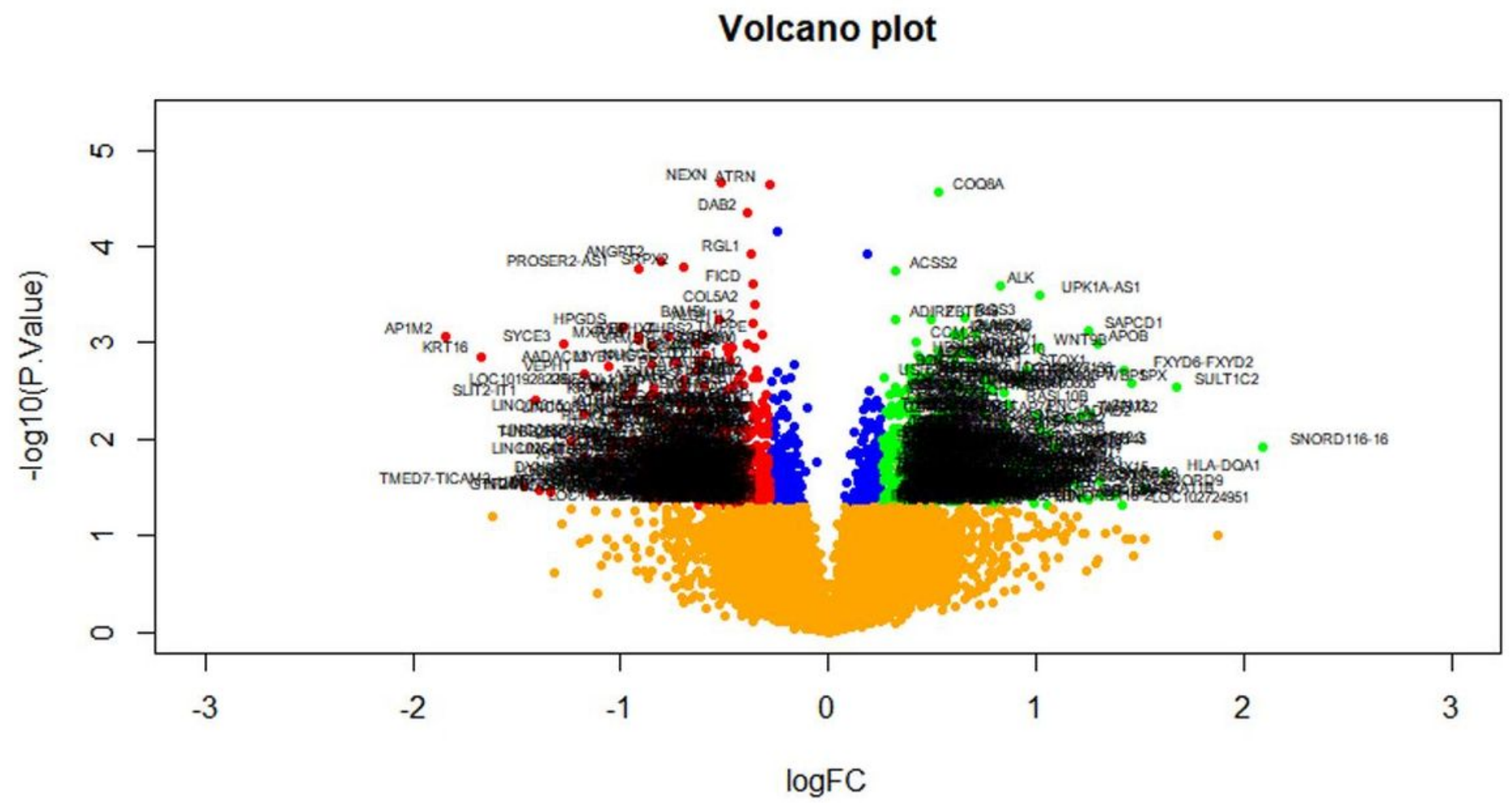

Figure 2

Volcano plot of differentially expressed genes. Genes with a significant change of more than two-fold were selected. Green dot represented up regulated significant genes and red dot represented down regulated significant genes. 
A

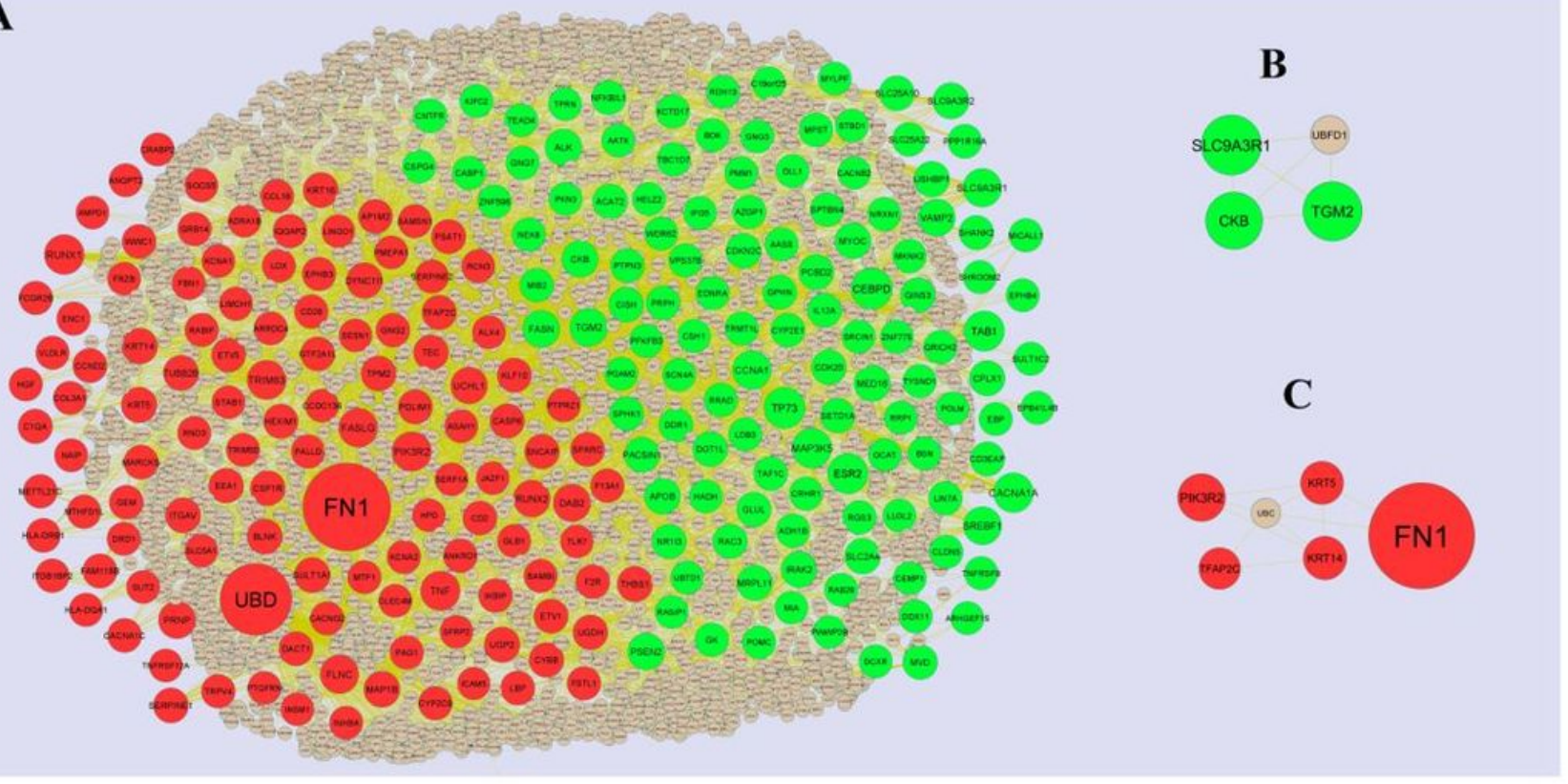

\section{Figure 3}

PPI network and the most significant modules of DEGs. (A) The PPI network of DEGs was constructed using Cytoscape (B) The most significant module was obtained from PPI network with 4 nodes and 6 edges for up regulated genes (C) The most significant module was obtained from PPI network with 6 nodes and 10 edges for down regulated genes. Up regulated genes are marked in green; down regulated genes are marked in red

A

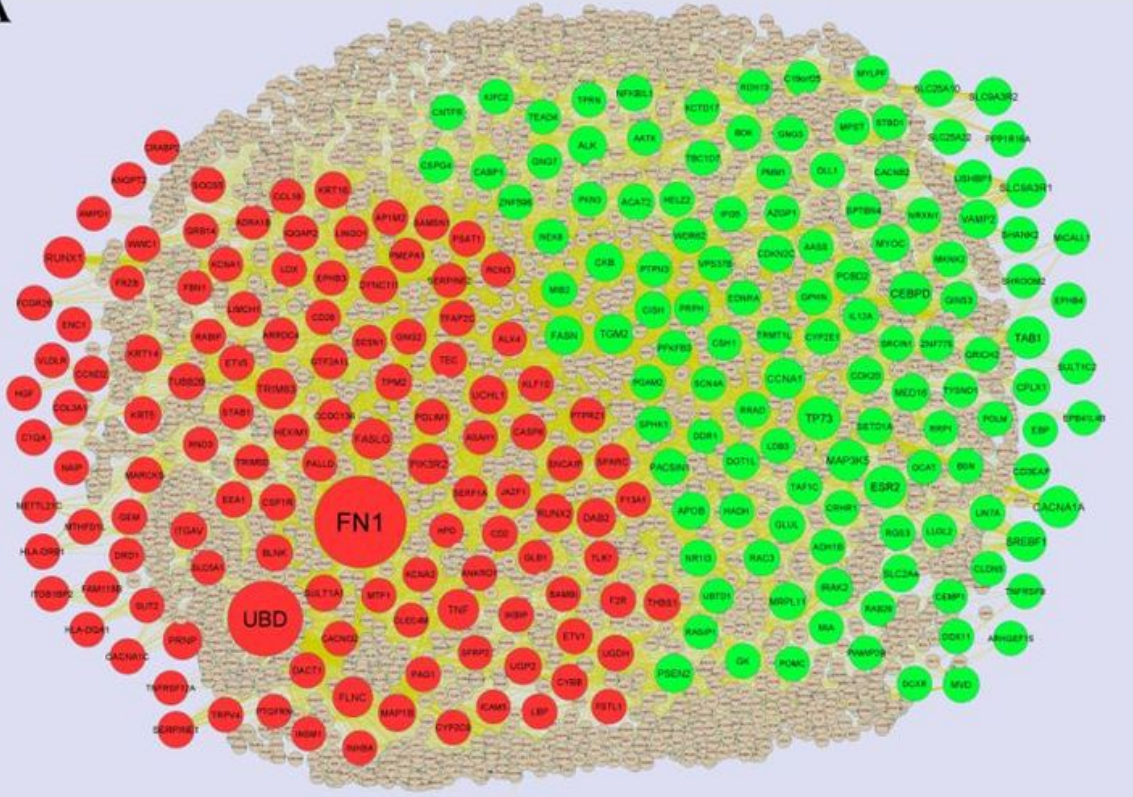

B SLC9A3R1 UBFo

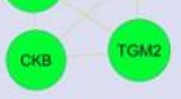

C



\section{Figure 3}


PPI network and the most significant modules of DEGs. (A) The PPI network of DEGs was constructed using Cytoscape (B) The most significant module was obtained from PPI network with 4 nodes and 6 edges for up regulated genes (C) The most significant module was obtained from PPI network with 6 nodes and 10 edges for down regulated genes. Up regulated genes are marked in green; down regulated genes are marked in red

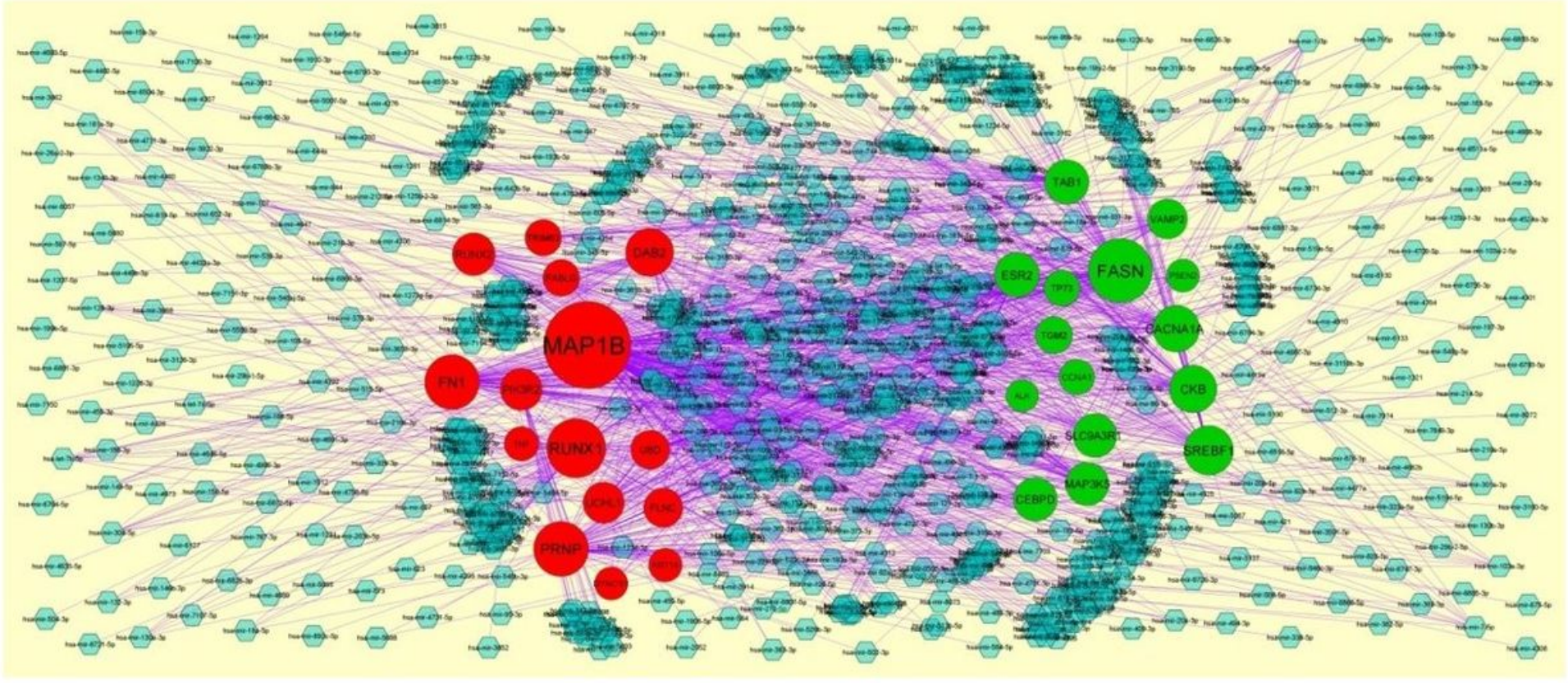

\section{Figure 4}

Target gene - miRNA regulatory network between target genes. The blue color diamond nodes represent the key miRNAs; up regulated genes are marked in green; down regulated genes are marked in red.

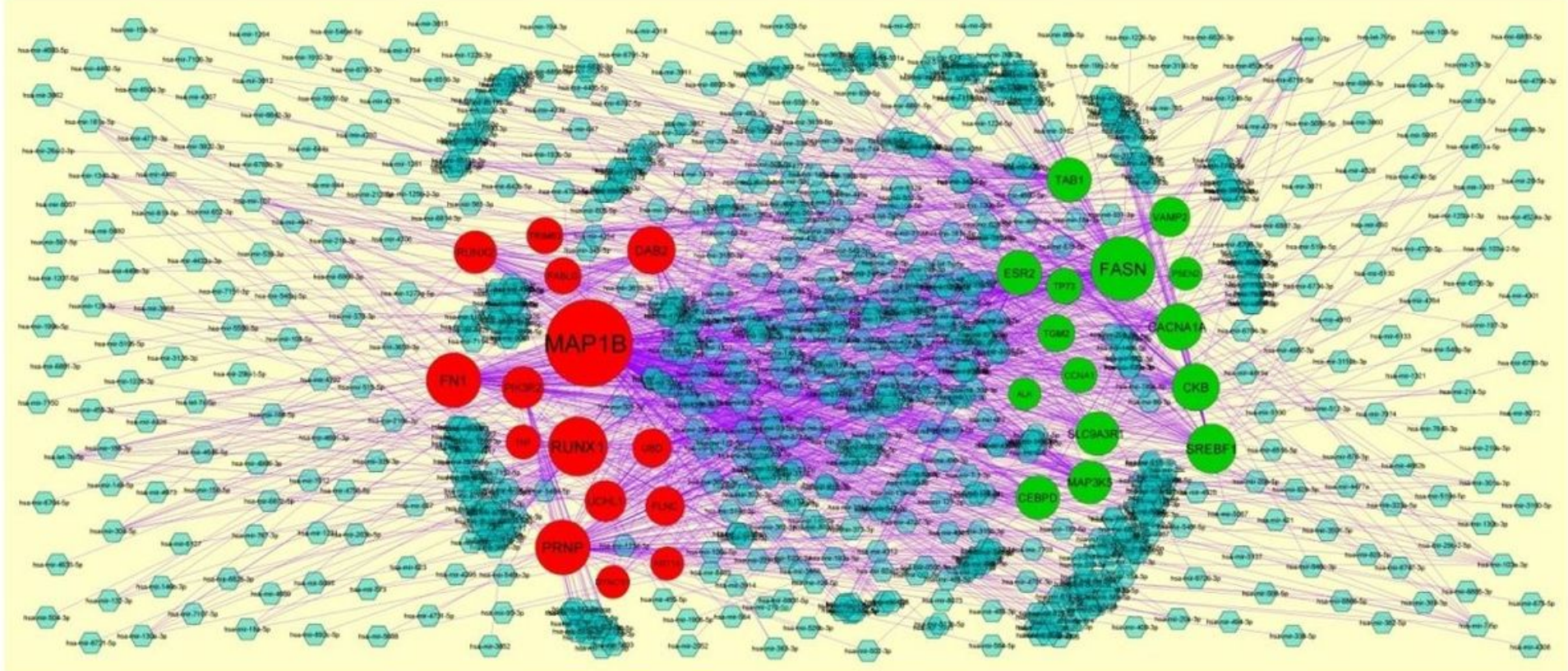

\section{Figure 4}


Target gene - miRNA regulatory network between target genes. The blue color diamond nodes represent the key miRNAs; up regulated genes are marked in green; down regulated genes are marked in red.

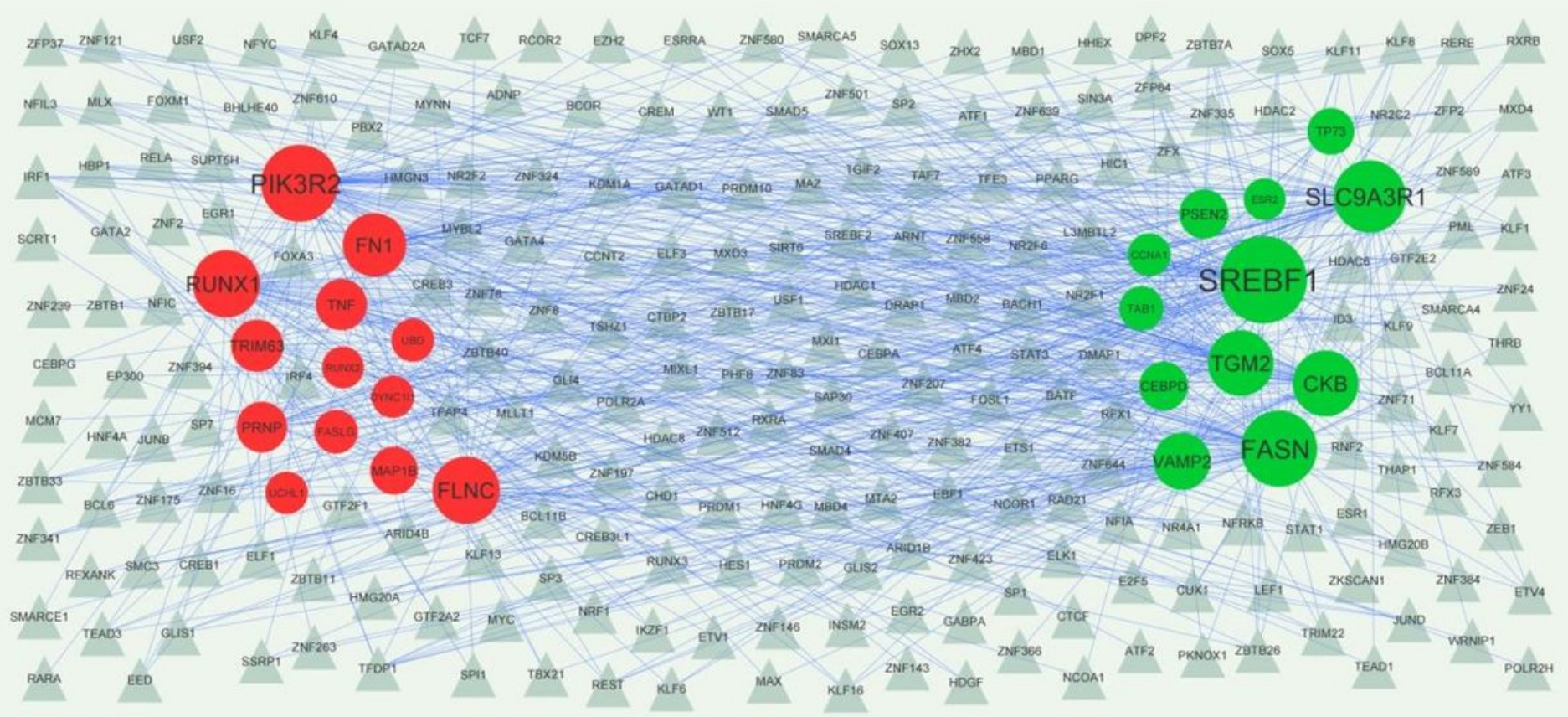

\section{Figure 5}

Target gene - TF regulatory network between target genes. The gray color triangle nodes represent the key TFs; up regulated genes are marked in green; down regulated genes are marked in red.

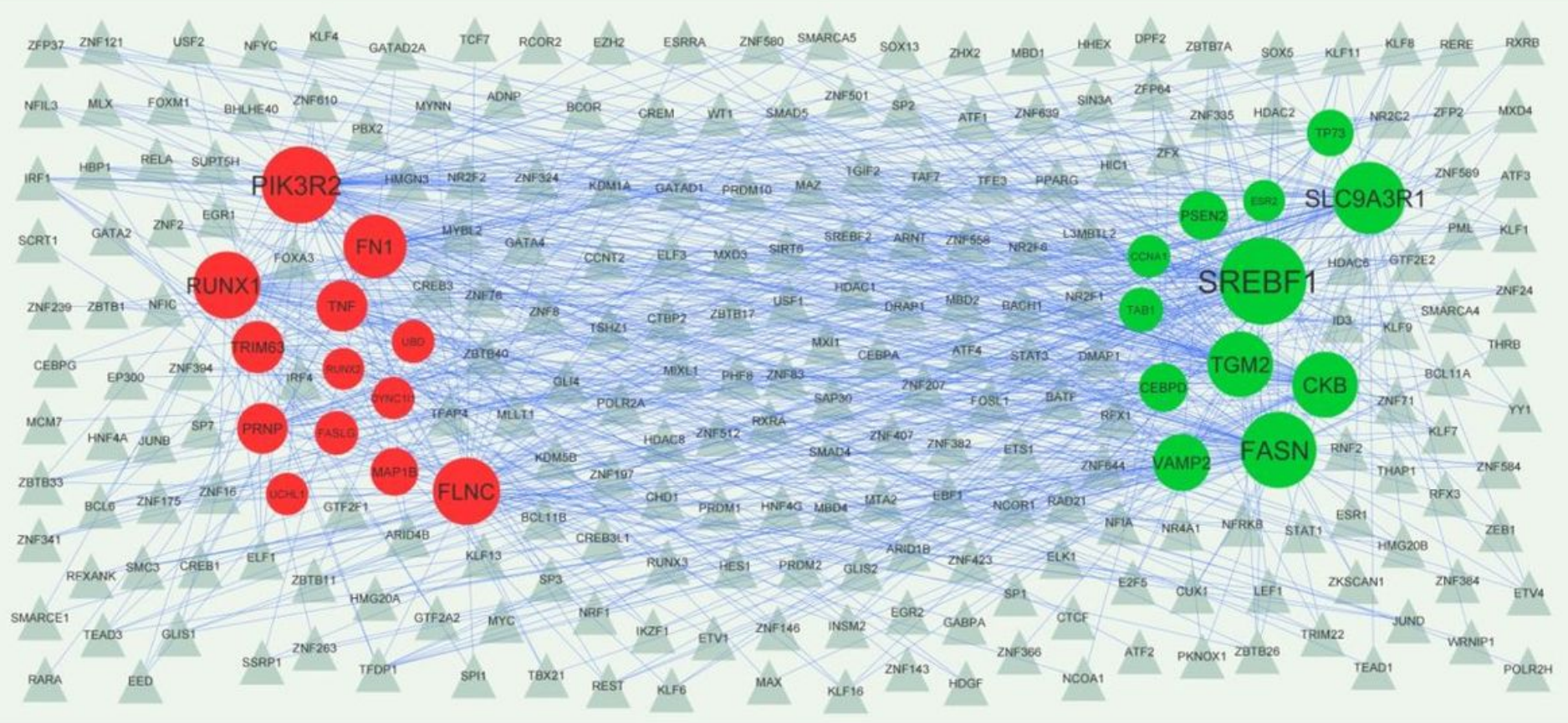

Figure 5 
Target gene - TF regulatory network between target genes. The gray color triangle nodes represent the key TFs; up regulated genes are marked in green; down regulated genes are marked in red.
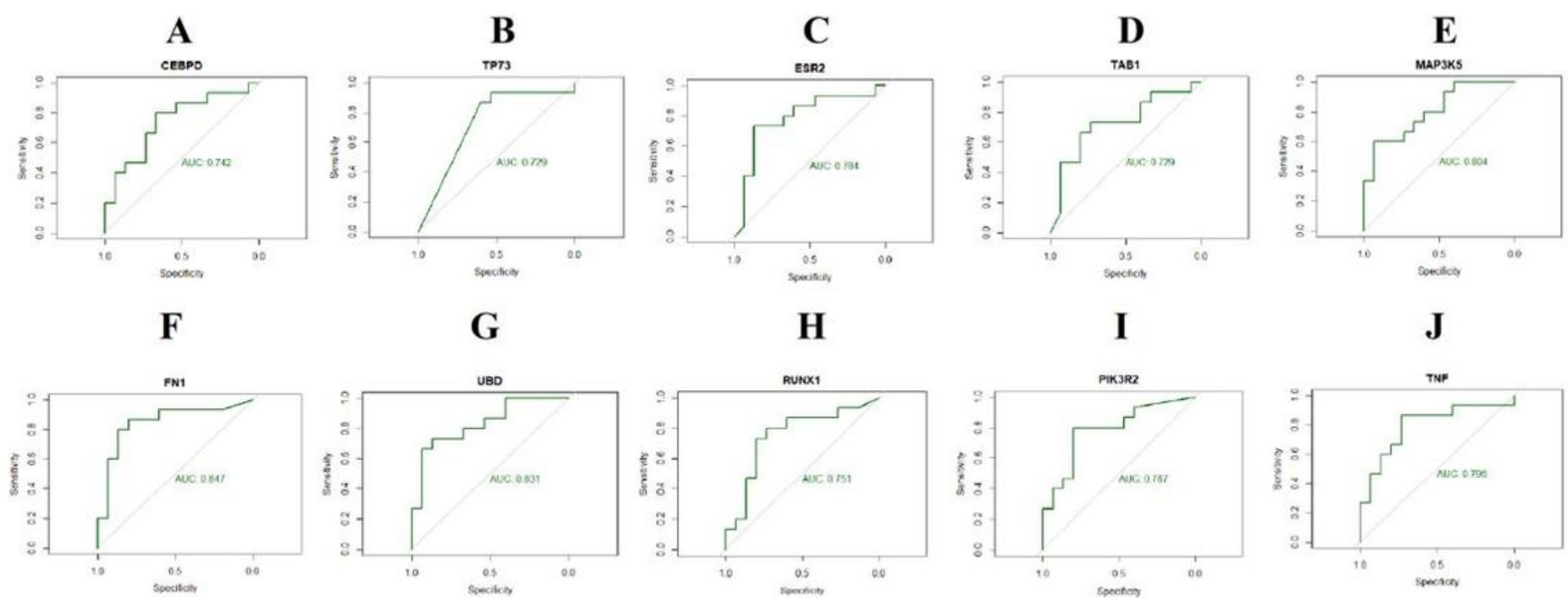

Figure 6

ROC curve analyses of hub genes. A) CEBPD B) TP73C) ESR2 D) TAB1 E) MAP3K5 F) FN1 G) UBD H) RUNX1 I) PIK3R2 J) TNF
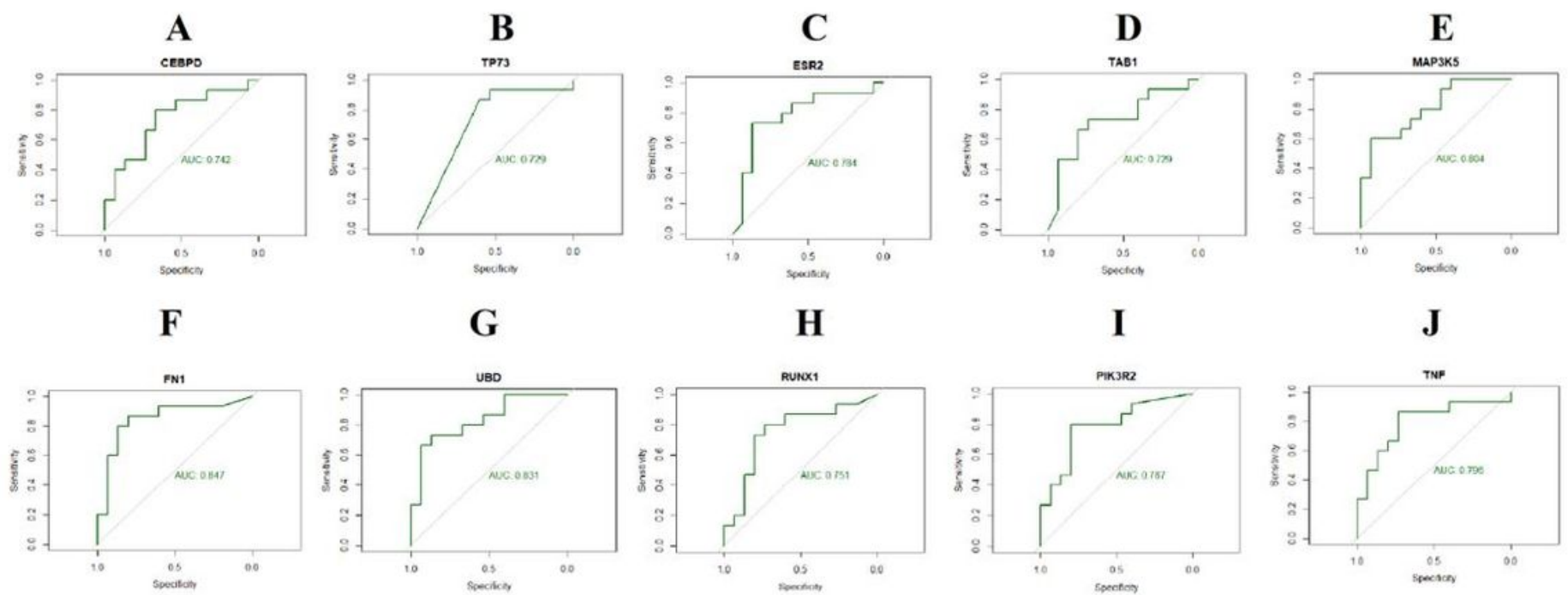

Figure 6

ROC curve analyses of hub genes. A) CEBPD B) TP73C) ESR2 D) TAB1 E) MAP3K5 F) FN1 G) UBD H) RUNX1 I) PIK3R2 J) TNF 

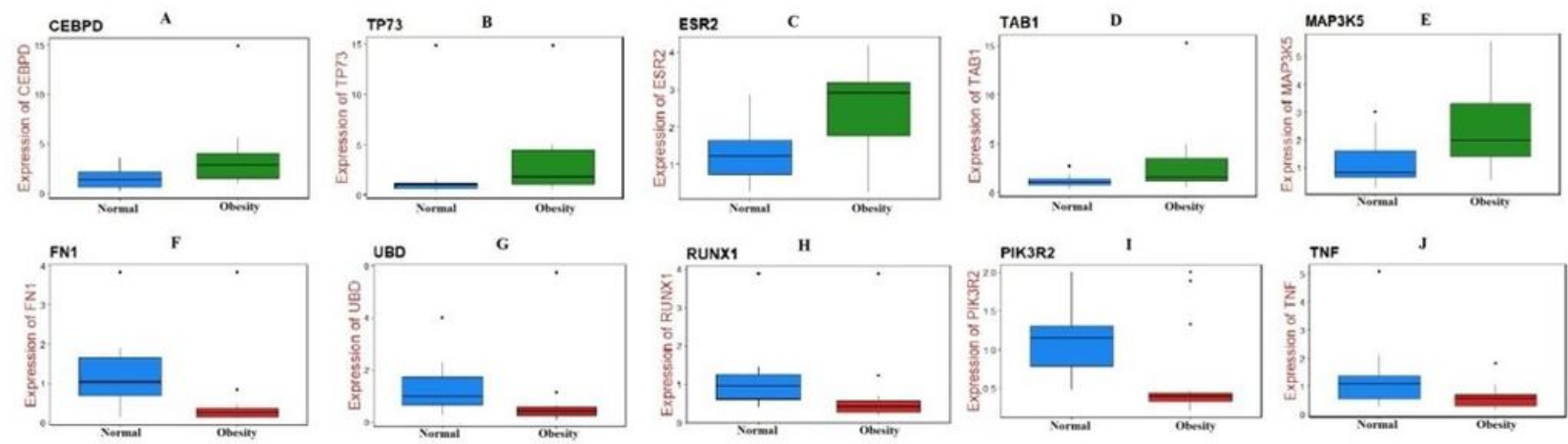

Normal

Up regulated (Obesity)

Down regulated (Obesity)

Figure 7

RT-PCR analyses of hub genes. A) CEBPD B) TP73C) ESR2 D) TAB1 E) MAP3K5 F) FN1 G) UBD H) RUNX1 I) PIK3R2 J) TNF
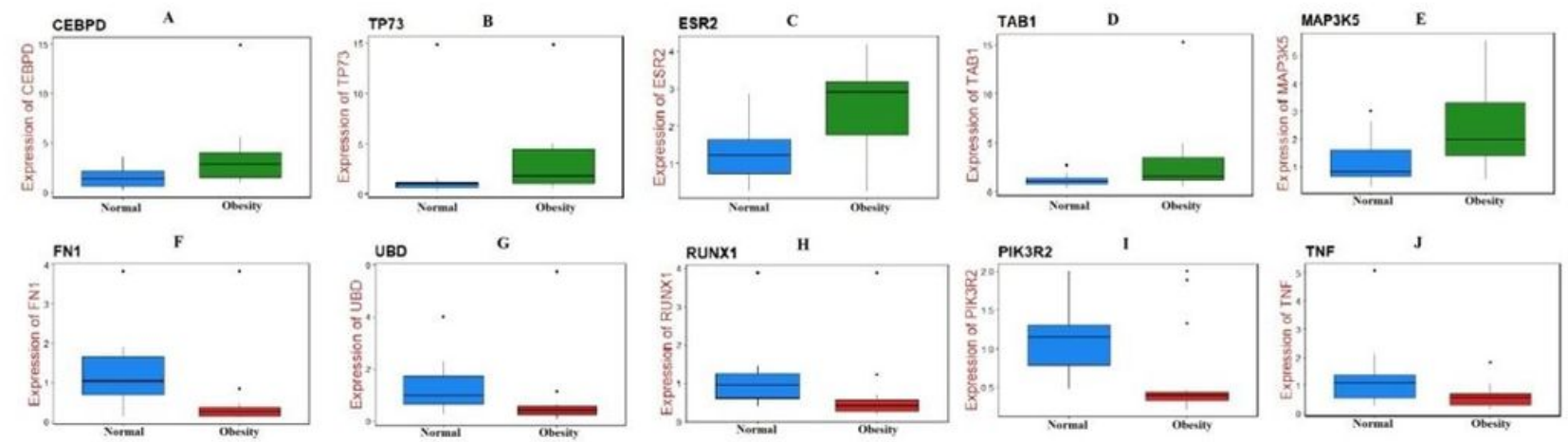

Normal

Up regulated (Obesity)

Down regulated (Obesity)

Figure 7

RT-PCR analyses of hub genes. A) CEBPD B) TP73C) ESR2 D) TAB1 E) MAP3K5 F) FN1 G) UBD H) RUNX1 I) PIK3R2 J) TNF 
$\mathrm{R}$ :<smiles>[R]c1cc(-c2ccc(CC3SC(=O)NC3=O)cc2O)nc(S)n1</smiles>

TZPSH<smiles>[R]c1cc(-c2ccc(CC3SC(=O)NC3=O)cc2O)nc(O)n1</smiles>

TZP
1<smiles>Cc1ccc(Cl)cc1</smiles>

1<smiles>Cc1ccc(O)cc1</smiles>

$\mathrm{Br}$<smiles>Cc1ccc(F)cc1</smiles>

5<smiles>Cc1ccc(C)cc1</smiles>

1
6<smiles>COc1ccc(C)cc1</smiles>

7<smiles>CNc1ccc(C)cc1</smiles>

9<smiles>Cc1ccc(N(C)C)cc1</smiles>

10<smiles>COc1cc(C)cc(OC)c1</smiles>

11<smiles>[R]c1cc(-c2ccc(CC3SC(=O)NC3=O)cc2O)nc(O)n1</smiles>

TZP

Figure 8

Structures of designed molecules

$\mathrm{R}$ :<smiles>[R]c1cc(-c2ccc(CC3SC(=O)NC3=O)cc2O)nc(S)n1</smiles><smiles>Cc1ccc(Br)cc1</smiles>

1<smiles>Cc1ccc(O)cc1</smiles>

4<smiles>CCc1ccc(C)cc1</smiles>

5<smiles>COc1ccc(C)cc1</smiles>

7<smiles>Cc1ccc(N)cc1</smiles>

8<smiles>CNc1ccc(C)cc1</smiles>

9<smiles>Cc1ccc(N(C)C)cc1</smiles>

10<smiles>COc1cc(C)cc(OC)c1</smiles>

11

\section{Figure 8}

Structures of designed molecules 


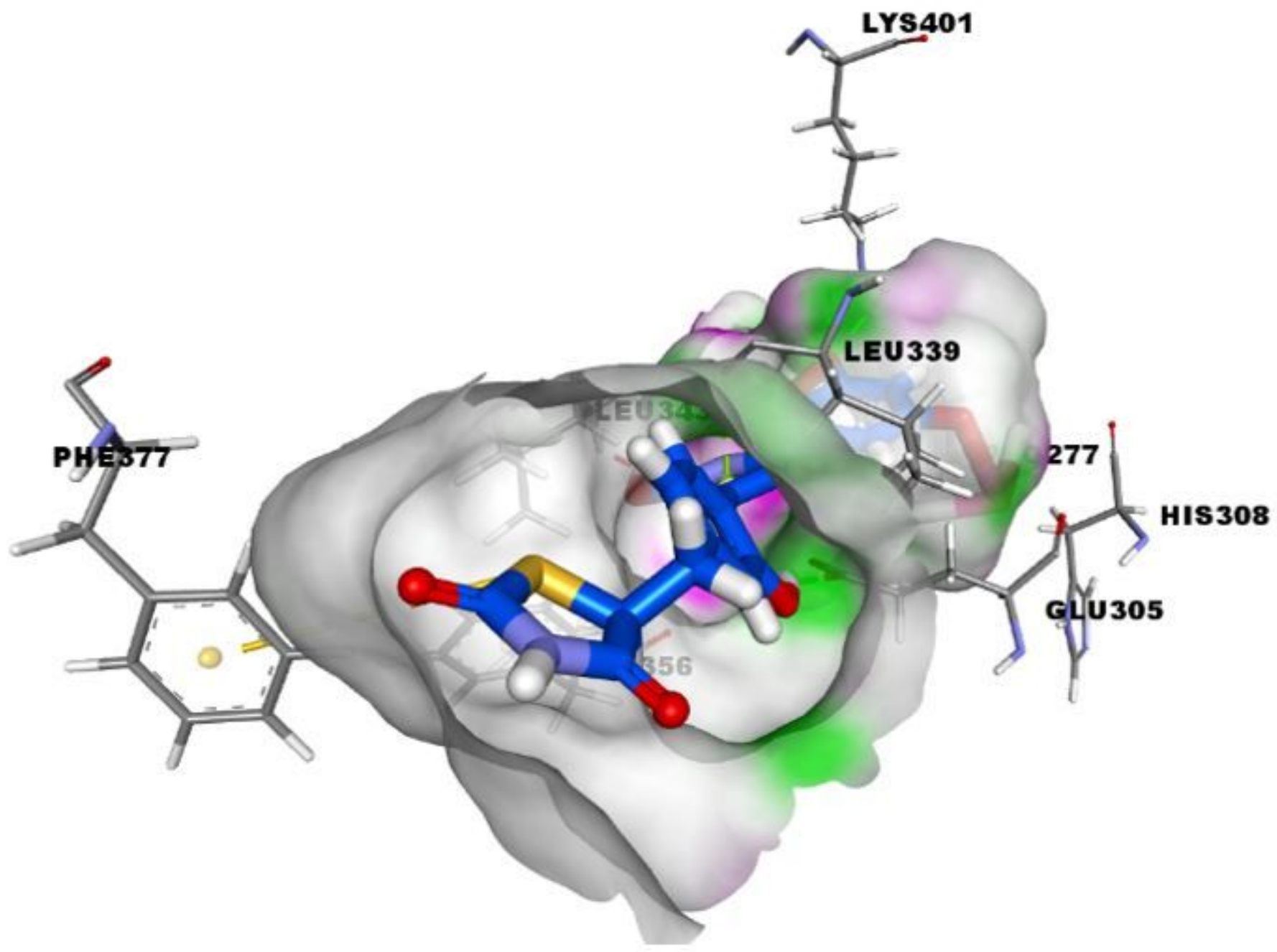

Figure 9

3D Binding of molecule TZP22with 2IOG 


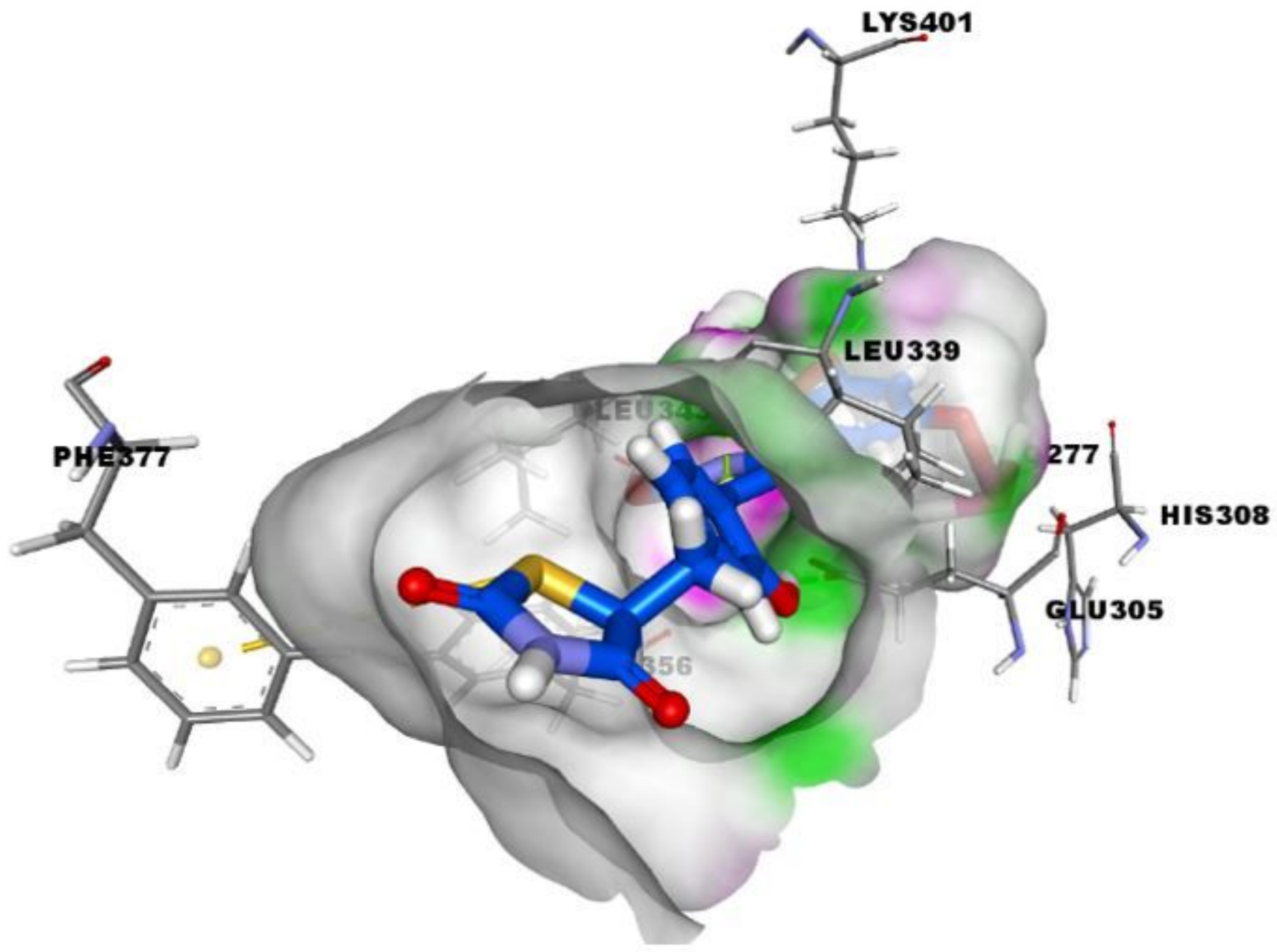

Figure 9

3D Binding of molecule TZP22with 2IOG 


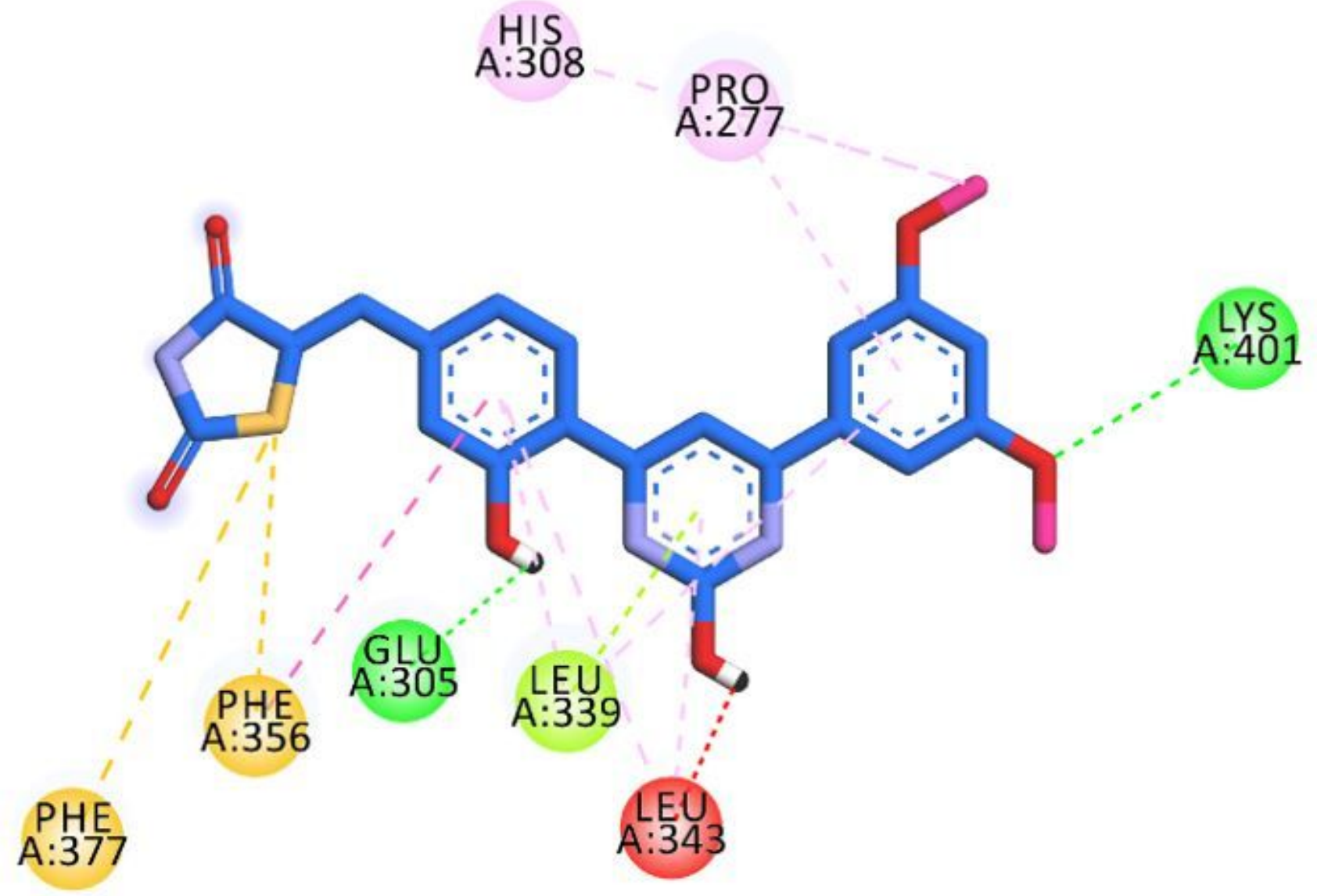

Figure 10

2D Binding of molecule TZP22with 2IOG 


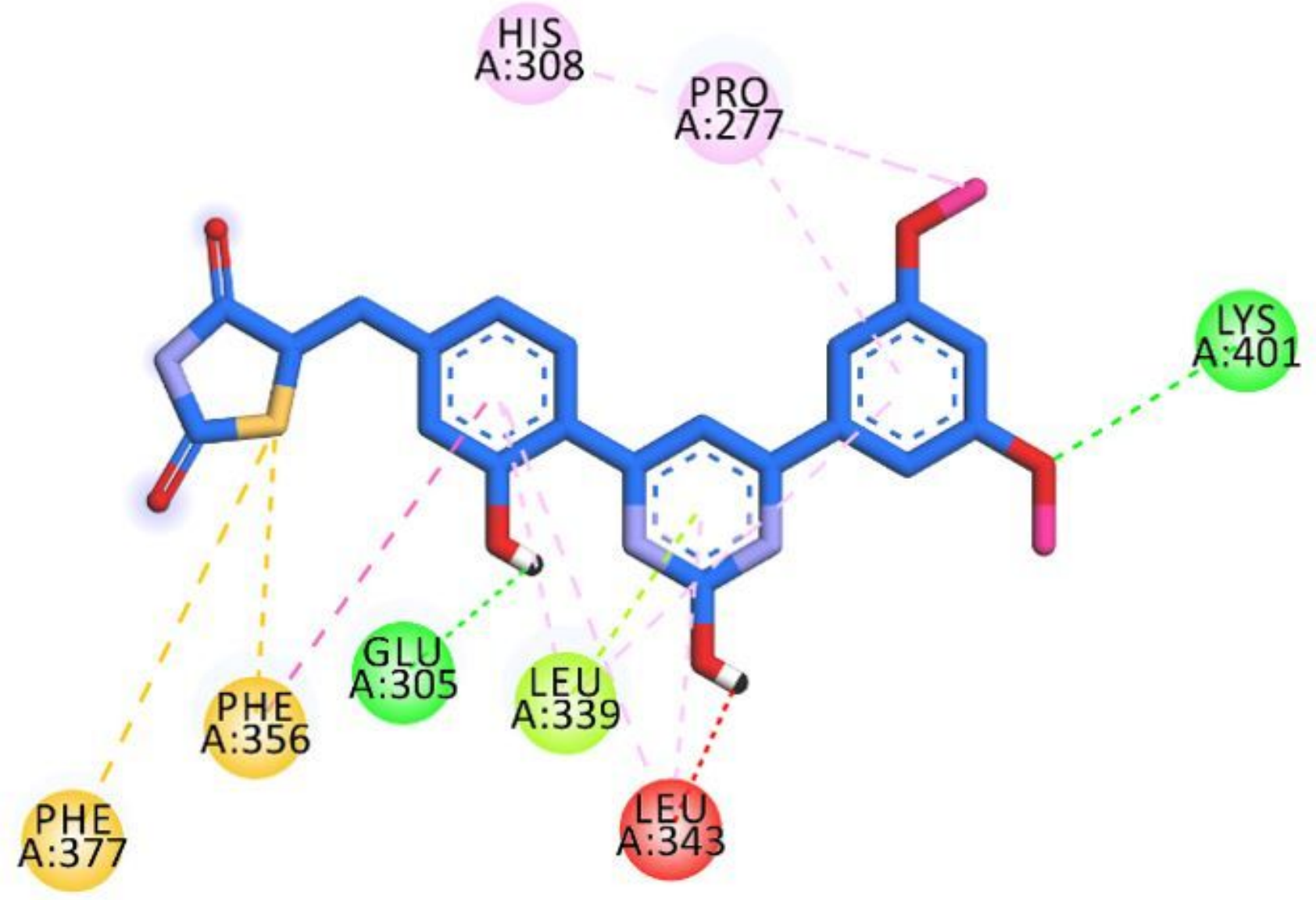

Figure 10

2D Binding of molecule TZP22with 2IOG

\section{Supplementary Files}

This is a list of supplementary files associated with this preprint. Click to download.

- BMCEndocrinedisordersTables.docx

- BMCEndocrinedisordersTables.docx 